\title{
GEOHYDROLOGIC FEASIBILITY STUDY OF THE GREATER GREEN RIVER BASIN FOR THE POTENTIAL APPLICABILITY OF JACK W. MCINTYRE'S PATENTED TOOL
}

\author{
By \\ P. Damian Reed
}

February 1994

Work Performed Under Jack McIntyre/DOE Contract No. DE-FG46-92R699202

For

Jack W. McIntyre

Fort, Stockton, Texas

And

\section{U.S. Department of Energy \\ Office of Scientific and Technical Information (OSTI) Oak Ridge, Tennessee}

\section{DISCLAIMER}

\begin{abstract}
This report was prepared as an account of work sponsored by an agency of the United States Government. Neither the United States Government nor any agency thereof, nor any of their employees, makes any warranty, express or implied, or assumes any legal liability or responsibility for the accuracy, completeness, or usefulness of any information, apparatus, product, or process disclosed, or represents that its use would not infringe privately owned rights. Reference herein to any specific commercial product, process, or service by trade name, trademark, manufacturer, or otherwise does not necessarily constitute or imply its endorsement, recommendation, or favoring by the United States Government or any agency thereof. The views and opinions of authors expressed herein do not necessarily state or reflect those of the United States Government or any agency thereof.
\end{abstract}




\section{CONTENTS}

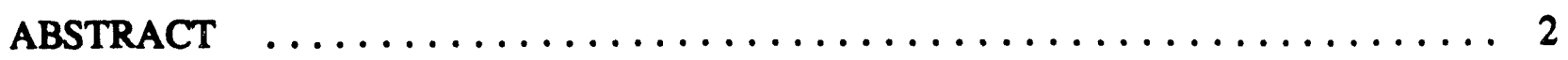

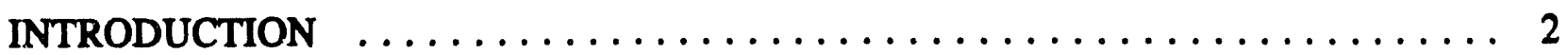

GEOLOGIC SETTING $\ldots \ldots \ldots \ldots \ldots \ldots \ldots \ldots \ldots \ldots \ldots \ldots \ldots$

GEOLOGIC STRUCTURE $\ldots \ldots \ldots \ldots \ldots \ldots \ldots \ldots \ldots \ldots, 6$

Western Wyoming Thrust Belt $\ldots \ldots \ldots \ldots \ldots \ldots \ldots \ldots \ldots 6$

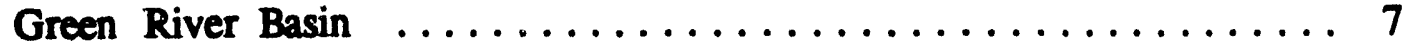

The Rock Springs Uplift $\ldots \ldots \ldots \ldots \ldots \ldots \ldots \ldots \ldots, 8$

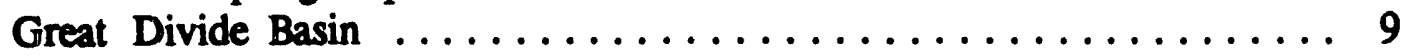

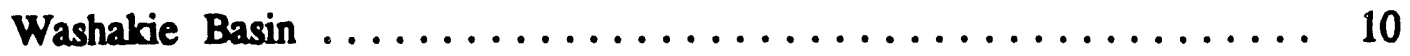

Sand Wash Basin $\ldots \ldots \ldots \ldots \ldots \ldots \ldots \ldots \ldots \ldots \ldots \ldots \ldots$

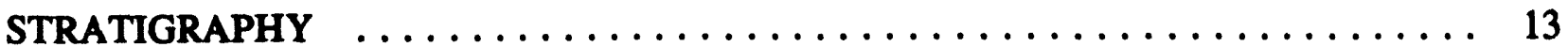

PRE-CAMBRIAN PERIOD $\ldots \ldots \ldots \ldots \ldots \ldots \ldots \ldots \ldots \ldots \ldots \ldots$

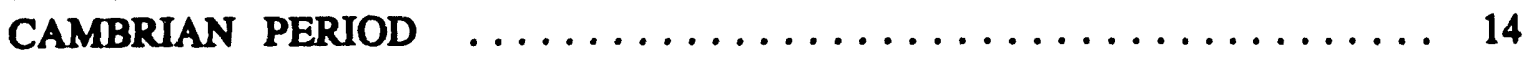

ORDOVICIAN PERIOD $\ldots \ldots \ldots \ldots \ldots \ldots \ldots \ldots \ldots \ldots \ldots, 15$

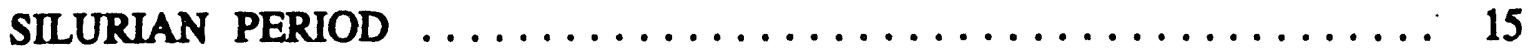

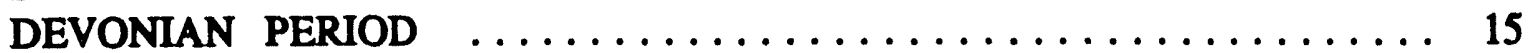

MISSISSIPPIAN PERIOD $\ldots \ldots \ldots \ldots \ldots \ldots \ldots \ldots \ldots \ldots \ldots, 16$

PENNSYLVANIAN PERIOD $\ldots \ldots \ldots \ldots \ldots \ldots \ldots \ldots \ldots \ldots \ldots, 16$

PERMIAN PERIOD $\ldots \ldots \ldots \ldots \ldots \ldots \ldots \ldots \ldots \ldots \ldots \ldots \ldots, 17$

TRIASSIC PERIOD $\ldots \ldots \ldots \ldots \ldots \ldots \ldots \ldots \ldots \ldots \ldots \ldots \ldots, 18$

JURASSIC PERIOD $\ldots \ldots \ldots \ldots \ldots \ldots \ldots \ldots \ldots \ldots \ldots \ldots \ldots \ldots$

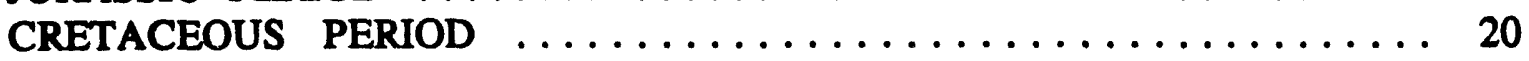

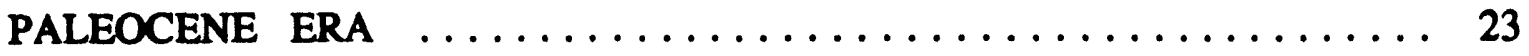

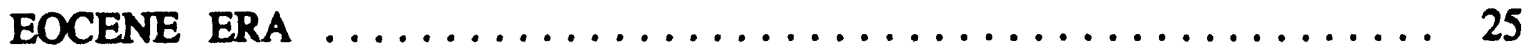

OLIGOCENE, MIOCENE, PLIOCENE AND PLEISTOCENE ERAS $\ldots .27$

COAL AND COALBED METHANE - OCCURRENCE, QUANTITY IN-PLACE ANDCHEMICAL CHARACTERISTICS $\ldots \ldots \ldots \ldots \ldots \ldots \ldots \ldots, 27$

COAL OCCURRENCE AND ESTIMATED COAL IN PLACE $\ldots \ldots \ldots, 27$

Green River Coal Region $\ldots \ldots \ldots \ldots \ldots \ldots \ldots \ldots \ldots \ldots \ldots \ldots$

Hams Fork Coal Region $\ldots \ldots \ldots \ldots \ldots \ldots \ldots \ldots \ldots \ldots, 31$

GREATER GREEN RIVER SUBORDINATE BASINS $\ldots \ldots \ldots \ldots \ldots, 31$

GREEN RIVER BASIN $\ldots \ldots \ldots \ldots \ldots \ldots \ldots \ldots \ldots \ldots \ldots \ldots, 31$

Great Divide Basin $\ldots \ldots \ldots \ldots \ldots \ldots \ldots \ldots \ldots \ldots \ldots, 32$

Washakie Basin $\ldots \ldots \ldots \ldots \ldots \ldots \ldots \ldots \ldots \ldots \ldots \ldots, 32$

Sand Wash Basin ......................... 32

Estimated Coal in Place and Chemical Characteristics ......... 33

COALBED METHANE OCCURRENCE $\ldots \ldots \ldots \ldots \ldots \ldots \ldots \ldots \ldots, 34$

Coalbed Methane Generation $\ldots \ldots \ldots \ldots \ldots \ldots \ldots \ldots \ldots, 34$

Biogenic and Thermogenic Coalbed Methane Generation ....... 35

Cleat Porosity and Permeability ................... 36 


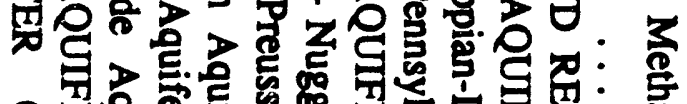

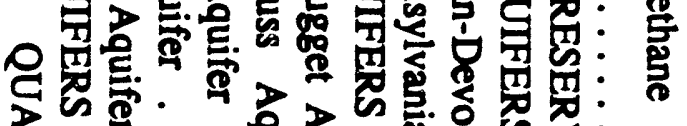

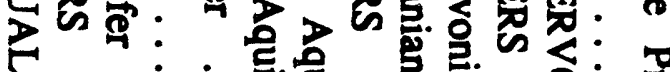

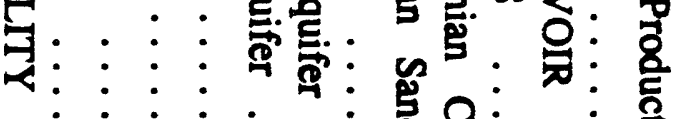

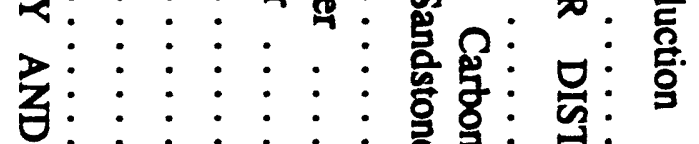

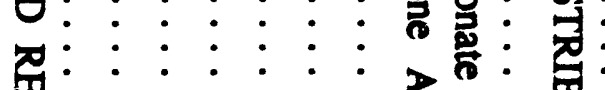

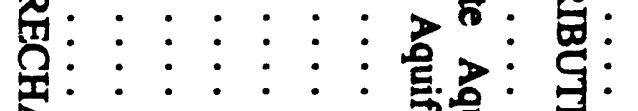

:

畐:

을:

罚:

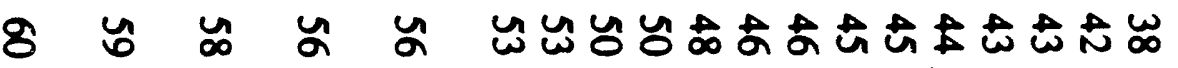




\title{
GEOHYDROLOGIC FEASIBILITY STUDY OF \\ THE GREATER GREEN RIVER BASIN \\ FOR THE POTENTIAL APPLICABILITY OF JACK W. MCINTYRE'S PATENTED TOOL
}

\begin{abstract}
Geraghty \& Miller, Inc. of Midland, Texas conducted geologic and hydrologic feasibility studies of the potential applicability of Jack McIntyre's patented tool for the recovery of natural gas from coalbed/sand formations in the Greater Green River Basin through literature surveys.
\end{abstract}

\section{INTRODUCTION}

The Greater Green River Basin has the potential, with additional development, of becoming one of the leading producers of coalbed methane gas in this country.

Historically, from areas of coalbed methane resources such as the San Juan Basin of New Mexico, most of the completed wells produce methane and wastewater (brine). The produced water is usually treated and released to a surface body of water in conformance with an NPDES permit. Costs can be high to construct, operate and maintain treatment facilities. Also, environmental regulations pertaining to the release of wastewater to surface waters of the United States are presently under governmental investigation. 
A new process patented by Jack McIntyre has both economic and environmental advantages over the conventional surface treatment and disposal of production water. This process has been tested in the Michigan Basin and reported to be successful. The process is based on utilizing a single well for both production and water disposal. During production, fluids enter the wellbore, the gas rises to the surface and water moves down into the disposal zone either by gravity or mechanical pumping. This method allows separation of gas with simultaneous disposal of the water without the economic and environmental obstacles of bringing the water to the surface. A description and discussion of Jack W. McIntyre's tool will be summarized in the compendium of the seven basins studied under this contract.

The objective of this investigation was primarily to identify the geologic and hydrologic parameters associated with the production of coalbed methane in the Greater Green River Basin for the potential use of Jack McIntyre's patented tool. The investigation includes the description of geologic formations in ascending order, the present-day structure of each formation, the stratigraphy of each formation as it applies to potential methane gas production and disposal, hydrologic conditions (formation pressure, fluid chemistry, etc.) and reservoir and production history. Published papers and reports were the primary sources of information utilized for this investigation. No field acquisition of data was performed during this investigation, and no testing of Jack McIntyre's tool in the Greater Green River Basin was done. 


\section{GEOLOGIC SETTING}

The Greater Green River Basin is located in southwestern Wyoming and northwestern Colorado. (Figure 1) It encompasses an area of approximately 21,000 square miles. The basin is bounded on the west by the western Wyoming Thrust Belt, on the south by the Unita Mountains and the Axial Basin anticline, on the east by the Sierra Madre and Rawlins Uplift, and on the north and northeast by the Gros Ventre and Wind River Mountains (Anderman 1956).

The Greater Green River Basin can be divided into six structural units: the western Wyoming Thrust Belt, the Green River Basin, the Rock Springs Uplift, the Great Divide Basin, the Washakie Basin and the Sand Wash Basin (McCord 1984) (Figure 2).

The climate of the Greater Green River Basin area is semi-arid with extreme temperatures ranging from 100 degrees Fahrenheit during the summer months to below -35 degrees Fahrenheit during the winter months. Precipitation ranges from a high of 17 inches at Kendall, Wyoming near the headwaters of the Green River to a low of 5 inches recorded in the Red Desert of the Great Divide Basin (National Oceanic Atmospheric Administration 1974) (McCord 1984). 


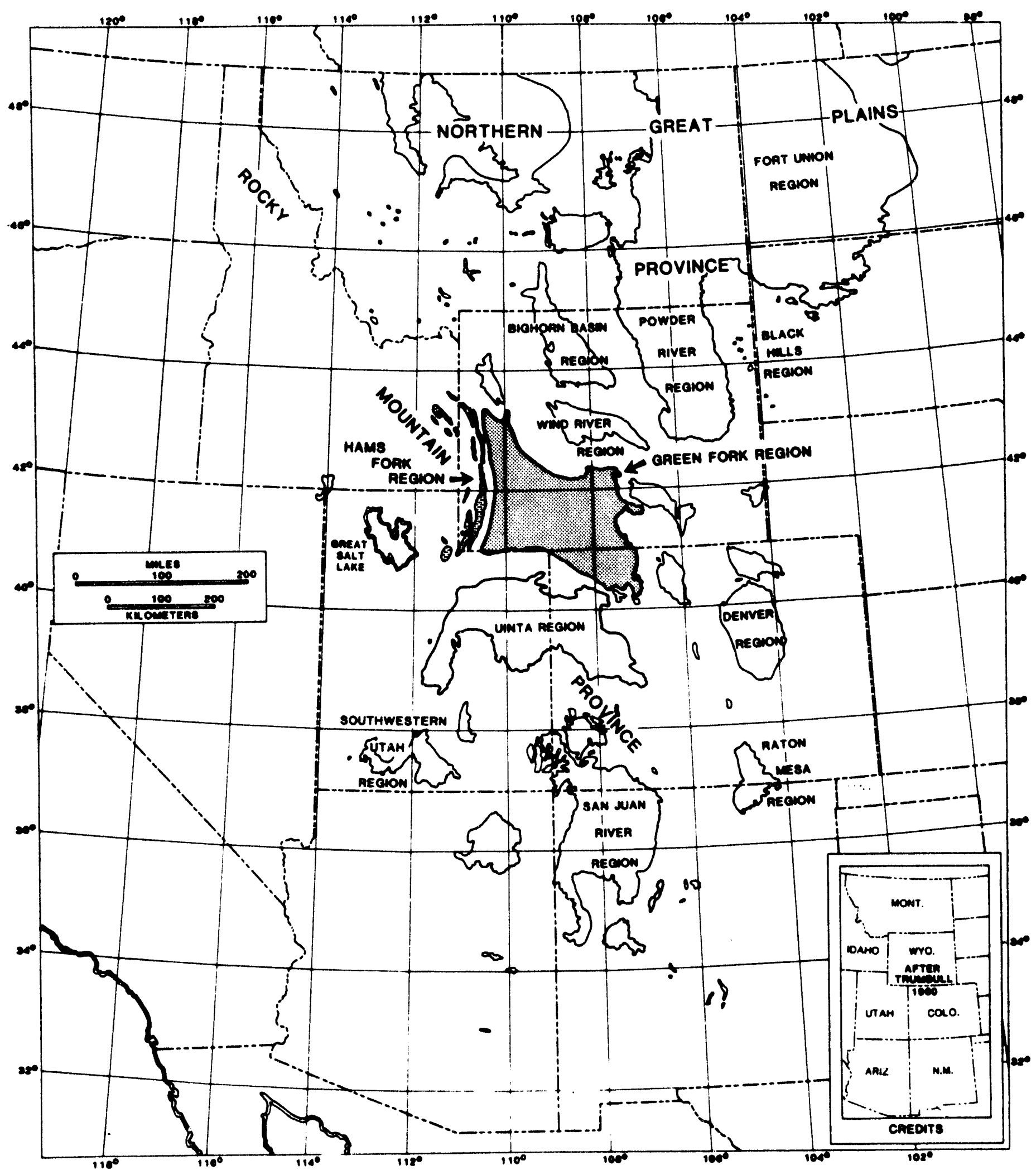

Figure 1. Regional Setting of the Greater Green River Coal Region (after McCord, 1984). 


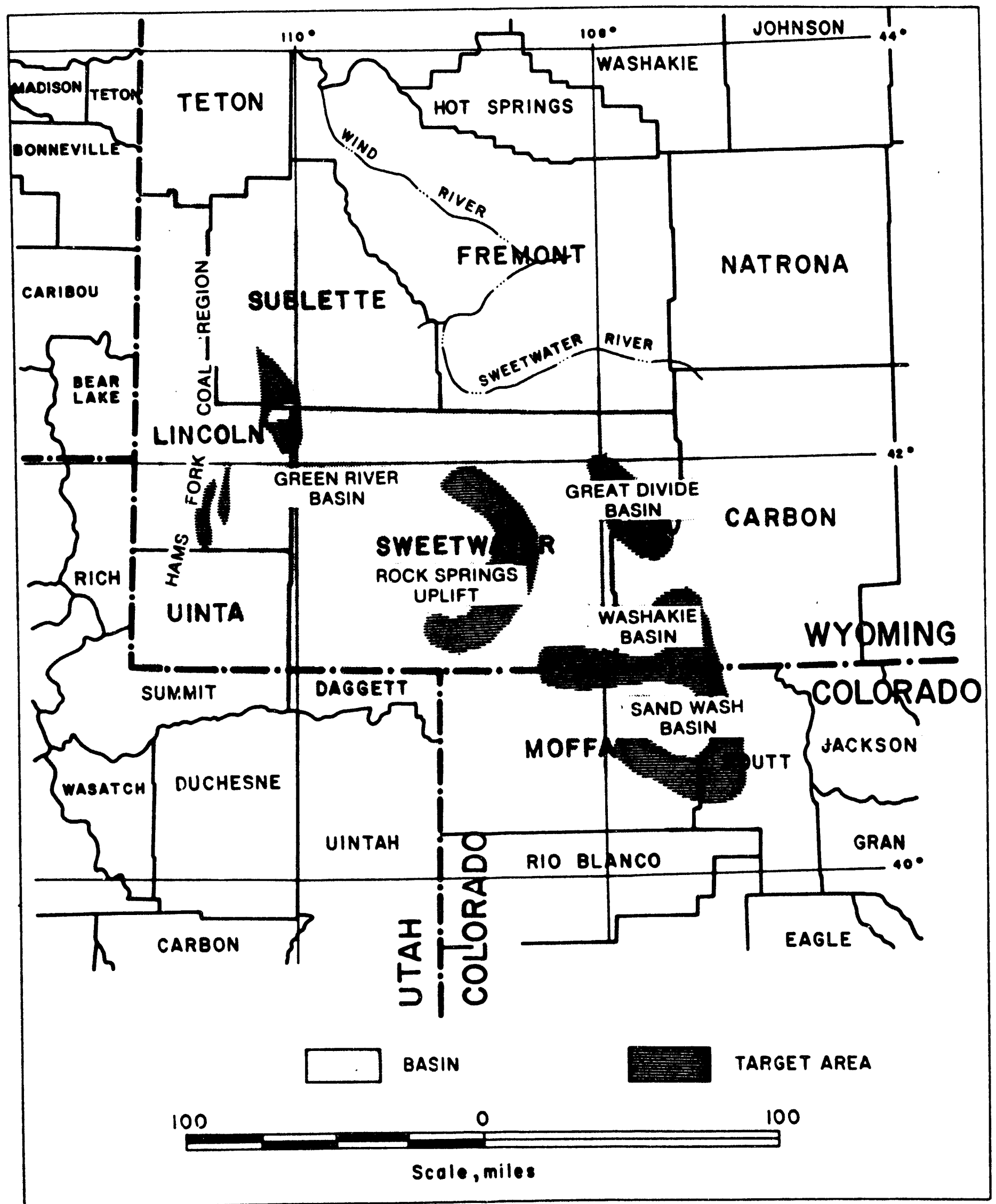

Figure 2. Structural Units of the Greater Green River Basin (after McCord, 1984). 
Mineral resources, tourism, transportation and agriculture are the primary economic base for the state. Natural gas, petroleum, trona (an impure form of hydrous sodium carbonate), coal, oil shale and uranium are the principal mineral resources within the state.

\section{GEOLOGIC STRUCTURE}

The Greater Green River Basin area includes six structural units. They are the western Wyoming Thrust Belt, the Green River Basin, the Rock Springs Uplift, the Great Divide Basin, the Washakie Basin and the Sand Wash Basin (McCord 1984).

\section{Western Wyoming Thrust Belt}

The western Wyoming Thrust Belt comprises a variety of structural features. Within the Hams Fork coal region, structural features include the Crawford Mountain thrust fault, the Absaroka thrust fault, the Lazeart Syncline and the Darby-Hogback-Prospect thrust fault group. There are also many concealed thrust faults underlying the Hams Fork Plateau (McCord 1984).

The Crawford Mountain thrust fault has been mapped from approximately three miles east of Woodruff, Utah to just west of Sage Wyoming and to a point approximately 15 miles north of Cokeville, Wyoming. The amount of vertical displacement of the thrust 
fault varies from 22,000 feet on the north end of the fault to 18,000 feet on the south end of the fault. The dip of the fault (angle at which the stratum is inclined from the horizontal) varies from 70 to 30 degrees in a westerly direction and exhibits an average dip of 40 degrees (McCord 1984).

\section{Green River Basin}

The Green River Basin is a broad synclinal axis in the western portion of the Greater Green River Basin and encompasses an area of approximately 10,000 square miles. The principal axis of the basin trends $\mathrm{N} 30^{\circ} \mathrm{E}$ and is located approximately 20 miles west of the axis of the Rock Springs anticline. The beds within the basin are essentially horizontal with the exception of the margins of the basin (McCord 1984).

The Green River Basin is bounded on the north and northeast by the Wind River Mountains. The Continental Fault and the Pinedale anticline are present at this contact and are associated with a thrust fault and deep synclinal basin (Berg, 1969). Sedimentary rocks attain a thickness of 30,000 feet in the trough of this deep syncline. Dips associated with the basin at the north and northeast margin are to the south and range from 0.5 to 5 degrees. The eastern margin of the basin is bounded by the Rock Springs Uplift where beds dip in a westerly direction at 3 to 12 degrees. The western margin of the basin is bounded by the Western Wyoming Thrust Belt where the beds dip in an easterly direction at 2 to 8 degrees (McCord 1984). 
The southern margin of the Green River Basin is much more complex. The southern portion of the basin is bounded by the northern flank of the Unita Mountains. The Henry's Fork and Unita faults are two prominent faults at the southern margin of the basin. The Henry's Fork fault is a high angle, reverse fault with the exception of the western end where the fault is normal. The Unita Fault is a vertical fault with the northern side downthrown. Seismic activity has shown that one of the deepest portions of the basin occurs on the northern side of this fault (Fidlar, 1950) (McCord 1984).

There are many fold structures within the Green River Basin, the most important of which is the Moxa Arch. The Moxa arch is a broad, gently-folded basement uplift which is approximately 120 miles long and extends from the north flank of the Unita Mountains to the Big Piney-La Barge Platform. The majority of the folding of the Moxa Arch occurred during the middle to upper Cretaceous. Extensive erosion removed the basal Mesa Verde from the Cretaceous. The Arch was then buried by middle Mesa Verde rocks of the Ericson Formation which were deposited on the unconformity. Younger Cretaceous and Tertiary sediments do not reflect this arch (McCord 1984).

\section{The Rock Springs Uplift}

The Rock Springs Uplift is located in southwestern Wyoming with the Green River Basin to the west, the Great Divide Basin to the northeast and the Washakie Basin to the southeast. Located within the central part of Sweetwater County, Wyoming, the Uplift is 
an anticlinal structure which occurred during the Laramide orogeny. The axis of the basin trends generally north-south. The axis plunges both north at 1.5 to 3 degrees and south at 4 degrees. The uplift is symmetrical with the western side of the basin dipping west at 10 to 15 degrees and the eastern side dipping east at 5 to 8 degrees (McCord 1984).

There are many normal faults within the area which exhibit throws of less than 100 feet (McCord 1984). These fauits trend in generally an east-west direction with some extending up to 15 miles long (Welder \& McGreevy 1966).

Pre-Cambrian rocks found in the Rock Springs Uplift are approximately 17,000 feet higher in elevation than the lowest pre-Cambrian rocks in the adjacent Green River and Washakie Basins (McCord 1984).

\section{Great Divide Basin}

The Great Divide Basin is a large topographic and structural basin that has mostly internal drainage. It is bordered on the west by the Rock Springs Uplift, on the north by the Wind River Mountains and Bison Basin, on the west by the Rawlins Uplift and on the south by the Wamsutter Arch (McCord 1984).

The Great Divide Basin is a simple synclinal basin which has been modified by folds and faults. The faults are widespread and are of relatively small scale. The axis of the 
basin, although varied, trends generally north to south in the southeastern portion of the basin and $\mathrm{N} 60^{\circ} \mathrm{W}$ on the northwestern portion of the basin. In the western and southwestern portion of the basin, the beds dip in an easterly and northeasterly direction at 2 to 3 degrees. In the eastern portion of the basin, the beds dip towards the west at 20 degrees. The northern portion of the basin is much more complicated than the rest of the basin due to normal faults that exist in the area. These faults are superimposed on a thrust fault which is associated with the Wind River and Green Mountains (McCord 1984).

\section{Washakie Basin}

The Washakie Basin is a shallow syncline which covers an area of approximately 3,000 square miles. The basin is located in south central Wyoming and northern Colorado. It is bordered on the north by the Great Divide Basin, on the northwest by the Rock Springs Uplift, on the southwest by the Green River Basin, on the south by the Sand Wash Basin and on the east by the Sierra Madre Uplift. The Washakie and the Great Divide Basins are separated by the Wamsutter Arch (McCord 1984).

At the margins, the beds dip predominantly towards the central portion of the basin. The beds along the north and east sides of the $W_{a}$-hakie Basin dip at an angle of 3 to 5 degrees, and the beds along the west and southwest sides of the basin dip at an angle of 8 to 12 degrees. The beds tend to flatten out away from the margins of the basin and eventually become generally horizontal (McCord 1984). 


\section{Sand Wash Basin}

The Washakie and Sand Wash basins are separated by the Cherokee Ridge which is a gentle westward plunging anticlinal structure. The Cherokee Ridge is located near the Wyoming/Colorado border (McCord 1984). Basement rock is observed in the Cherokee at elevations less than 1,500 feet above the lowest point in the Sand Wash Basin and from between 1,500 and 2,000 feet above the lowest point in the Washakie Basin (Haun 1962).

The Sand Wash Basin is a southeasterly trending synclinal structure which is an extension of the Washakie Basin. The axis of the basin trends from the southeastern flank of the Rock Springs Uplift in a southeasterly direction towards Craig County, Colorado. The basin is bounded on the north by the Cherokee Ridge, on the east by the Sierra MadrePark Range, on the southeast by the folds associated with the axial fold belt and on the southeast by the Unita Mountains Uplift (McCord 1984).

At the deepest part of the Sand Wash Basin, the top of the pre-Cambrian is estimated to be 17,500 feet below sea level. In the Unita Mountains to the southeast, the Cambrian rocks are found at an elevation of 9,000 feet above sea level. Given this information, the structural relief of the basin is estimated at 26,500 feet. This vertical difference in elevation is observed over a horizontal distance of 30 miles. In the Park Range located on the easterm flank of the basin, the highest pre-Cambrian rocks are found 


\section{STRATIGRAPHY}

Sedimentary rocks found in the Greater Green River Basin range in age from the lower Cambrian to the Quaternary. These sediments can be divided into two broad groups: Paleozoic/Mesozoic and Cretaceous/Cenozoic. These two groups are divided on the basis of depositional environment. The Paleozoic/Mesozoic sediments were formed predominantly in marine environments. The Cretaceous/Mesozoic sediments which tend to be thinner than the Paleozoic/Mesozoic sediments were formed predominantly in continental environments. Together, these two types of depositional environments are responsible for the deposition of up to 40,000 feet of sediment (Thomas 1949). The coalbearing formations of the Greater Green River Basin are found in the Cretaceous/Cenozoic sequence. In order to better understand the coal-bearing strata of the basins, the following is a discussion of the stratigraphy of the area from Pre-Cambrian to Recent. This discussion will cover the stratigraphy of Wyoming and northern Colorado with emphasis on the Greater Green River Basin.

\section{PRE-CAMBRIAN PERIOd}

Pre-Cambrian rocks are exposed in cores of many of the mountain ranges in the Greater Green River Basin area. It is evident that a long period of deposition occurred on an unknown crust. This thick sequence of sediments then went through regional metamorphism and folding. Large batholiths then intruded the folded and metamorphosed 
sediments. Granite is the primary rock type found in these batholiths although many other rock types are present. After this long history of sedimentation, metamorphism, folding and igneous intrusions, wide spread erosion took place reducing the area to a peneplain by Cambrian time (Thomas, 1949).

\section{CAMBRIAN PERIOD}

In the early Cambrian period, the entire state of Wyoming was emergent. The early Cambrian sea was restricted to the Cordilleran Trough located west of Wyoming. This sea transgressed in a eastern direction and did not reach the western border of Wyoming until the middle Cambrian. The sea continued to transgress eastward throughout the Cambrian Period. Middle Cambrian rocks found in the Greater Green River Basin are the Flathead sandstone which is a transgressive sandstone sequence overlain by the Gros Ventre shale. The Flathead sequence both thins and gets younger to the east (Thomas 1949).

By the end of the Middle Cambrian, the sea had covered approximately one third of the western portion of the state which includes the Greater Green River Basin. During the Upper Cambrian, all but the southeastern portion of the state was submerged. It was during this time that the Gallatin Formation, an offshore limestone, was deposited. Wyoming was completely emergent at the end of the Cambrian time. The most widely distributed rocks in Wyoming are from the upper Cambrian. The lack of Late Cambrian 
rocks in the vicinity of the Greater Green River Basin suggests that pre-Ordovician erosion removed these rocks (Thomas 1949).

\section{ORDOVICIAN PERIOD}

The Greater Green River Basin, as well as the majority of the state, remained emergent until late in Ordovician time. The Big Horn Dolomite, which is composed of a dense, massive, pure dolomite, was deposited in the latter part of the Ordovician. Both the Cambrian and the Ordovician deposits thin in an eastward direction as a result of the transgression of the Cambrian sea and the regression of the sea late in Ordovician time (Thomas 1949).

\section{SILURIAN PERIOD}

By the end of the Ordovician, the entire state was once again emergent. The greater Green River Basin, as well as the state remained emergent throughout Silurian time. As a result, there is no evidence of Silurian-age deposits in the basin (Thomas 1949).

\section{DEVONIAN PERIOD}

By Late Devonian, the western and northwestern portion of the state was once again submerged facilitating the deposition of the Darby Formation. The Darby Formation is of 
Middle to Late Devonian age. Although the Darby shows signs of thinning in an easterly direction, thicknesses of up to 200 feet are observed in the Wind River Mountains. The formation is composed of brown granular dolomite, red shale and some sandstones. This formation is missing over the eastern portion of the state (Thomas 1949).

\section{MISSISSIPPIAN PERIOD}

It is possible that for the first time, the entire state was submergent during Mississippian time. The Madison limestone which is seen throughout much of the Rocky Mountain region was deposited during early Mississippian (Thomas 1949).

\section{PENNSYLVANJA: PERIOD}

The Pennsylvanian rocks of Wyoming are the oldest rocks which can be seen widespread throughout the state. Although somewhat complex and changing over a very short period (both areal and time), the Pennsylvanian can be divided into four major rock facies. The Fountain Formation located in the southeastern portion of the state is comprised of a continental arkose coarse sandstone sequence. This formation interfingers with a marine strata to the north and loses its identity. In the northeastern portion of the state, a limestone facies dominates the Pennsylvanian Period. This limestone facies thins to the west and south. The Pennsylvanian Period is represented by a cross-laminated 
sandstone facies in the vicinity of the Greater Green River Basin. The fourth facies is comprised of an evaporite sequence of the Minelusa located in the Lance Creek field.

These four distinct facies become complex in areas where they transition from one to the other. The age of these four major facies vary such that some may occur throughout Pennsylvanian time and even into the Early Permian while others are restricted to only the Early Pennsylvanian. This variation in age is attributed to the fact that the Pennsylvanian Sea covered the state early in Pennsylvanian time and retreated westard through later Pennsylvanian time, restricting the older beds to the western portion of the state. This retreat of the sea continued through Late Pennsylvanian time and by the end of the Period and into Permian time, the state was entirely emergent (Thomas 1949).

\section{PERMIAN PERIOD}

In the area of the Greater Green River Basin in early Permian time, the state was entirely emergent. However, an arctic sea encroached the area during the Middle Permian. This led to the deposition of the well known Phosphoria Formation which is comprised of a black phosphate shale overlain by a cherty limestone exhibiting an overall thickness of 300 feet. The depositional environment of this phosphate rock was unique given that an associated siltstone deposition contains vanadium of extremely large amounts. (Thomas 1949). 


\section{TRIASSIC PERIOD}

Due to the fact that there was no folding during late Paleozoic time, Mesozoic rocks rest on Paleozoic rocks without any angular unconformity. The Greater Green River Basin was subject to submergence during early Triassic time by a sea which transgressed from southeastern Idaho and spread later into eastern Wyoming. This resulted in the deposition of a brownish orange to light brown siltstone and shale named the Dinwoody Formation. Following the deposition of the Dinwoody Formation, the Chugwater Formation comprised of a red shale was deposited in the areas of the Rawlins Uplift, Great Divide Basin and the Washakie Basin. During the deposition of the Chugwater Formation, normal marine sedimentation continued in the western portion of the Greater Green River Basin resulting in the deposition of the Thaynes Formation which is a thick limestone. The Thaynes Formation can be seen in the Wyoming Thrust Belt and the Green River Basin (Thomas 1949).

Following the deposition of the Chugwater Formation, a marine transgression occurred which resulted in the deposition of the Alcova Formation which is a thin limestone deposit seen in the eastern portion of the Greater Green River Basin. This formation is generally considered a tongue of the Thaynes Formation (Thomas 1949).

The stratigraphy of the upper Triassic beds is not very well understood. Sediments found above the Alcova Formation are composed of varicolored clays, sandstones and 
conglumerates. These formations are primarily seen in the Rawlins Uplift, the Great Livide Basin and the Washakie Basin. The lack of Alcova Limestone in the western portion of the Greater Green River Basin suggests pre-Jurassic erosion (Thomas 1949).

\section{JURASSIC PERIOD}

The lower Triassic is marked by a thick, cross-bedded sandstone sequence known as the Nugget formation. The Nugget thins eastward and is overlain by the Twin Creek formation which is composed of a thick marine limestone. This in turn is overlain by a red siltstone formation and a sandstone formation known as the Preuss and Stump formations, respectively. Toward the East and southern portion of the Greater Green River Basin, the Twin Creek, Preuss and Stump are represented by the Sundance Formation. The Sundance formation is composed primarily of variable sequences of sandstone and shale (Thomas 1949).

At the western portion of the Greater Green River Basin, the strata of the Jurassic comprise up to 5,000 feet of sediments. Sediments of Jurassic age thin to the east where on the eastern side of Wyoming attain a thickness of only a few hundred feet (Thomas 1949).

The termination of the Sundance era marked the end of marine conditions and the beginning of continental depositional environments and the subsequent deposition of the 
Morrison Formation. This formation is composed of a variegated shale which thins to the east. In the western portion of the Greater Green River Basin, it is difficult to distinguish the Morrison Formation from a overlying, somewhat similar formation of Lower Cretaceous age (Thomas, 1949).

\section{CRETACEOUS PERIOD}

During the early Cretaceous, the Greater Green River Basin area was subject to subareal erosion. Sedimentary rock units are predominantly fluvial conglomeratic sandstones and varicolored shales. Orogenic activity (deformation of rock units through folding and thrust faults) which occurred to the west of the basin helped to contribute conglomerates and coarse clastics eastward. These sediments were deposited in the vicinity of the Wyoming/Idaho border which at that time was the trough of a slowly subsiding asymmetrical basin (Thomas 1949).

The Garnett Group rests conformable on the Upper Jurassic Morrison Formation and is thought to be formed by early Cretaceous lakes. The Gamett Group is composed of basal conglomerates, conglomerate/sandstone units, fresh water limestone units and red calcareous mudstones.

The end of the lower Cretaceous time was marked by the first marine transgression of the Cretaceous period. This marine transgression came form the north and created a 
narrow seaway which stretched from the Gulf of Mexico to the Arctic Ocean. This resulted in the deposition of a sandstone/shale sequences which, across the Greater Green River Basin, are correlative and transgressive. These sedimentary sequences, from west to east, are the Bear River Sandstone-Aspen Shale, the Dakota Sandstone-Mowry Shale, the Fall River Sandstone-Thermorolis Shale and the Muddy Sandstone-Mowry Shale (Figure 3). These lower Cretaceous sandstone units are comprised of interbedded shales, coal, mudstones and fresh water limestones (McCord, 1984).

The late Cretaceous was marked by four transgressive-regressive cycles. They are, from oldest to youngest, the Greenhorn, the Niobrara, the Claggett and the Bearpaw (McGookey 1972). The transgressive cycle of the Greenhorn resulted in the deposition of the Frontier Formation. Uplifts in Idaho and northern Utah provided the clastic sediments for this formation. This supply of clastics resulted in a rapid deposition in a deltaic environment, of which the Frontier Formation reflects. The Frontier Formation consists of sandstone, siltstone, coalbeds and shaley claystones. The regressive cycle which occurred late in the Greenhorn cycle resulted in the deposition of the Mancos and Baxter Shale which are composed of great thicknesses of dark gray marine shale. This deposition continued through the Niobrara cycle (McCord 1984).

The most significant occurrence during the regressive cycle of the Niobrara was the development of coal from swamps. These swamps occurred during the retreat of the sea 

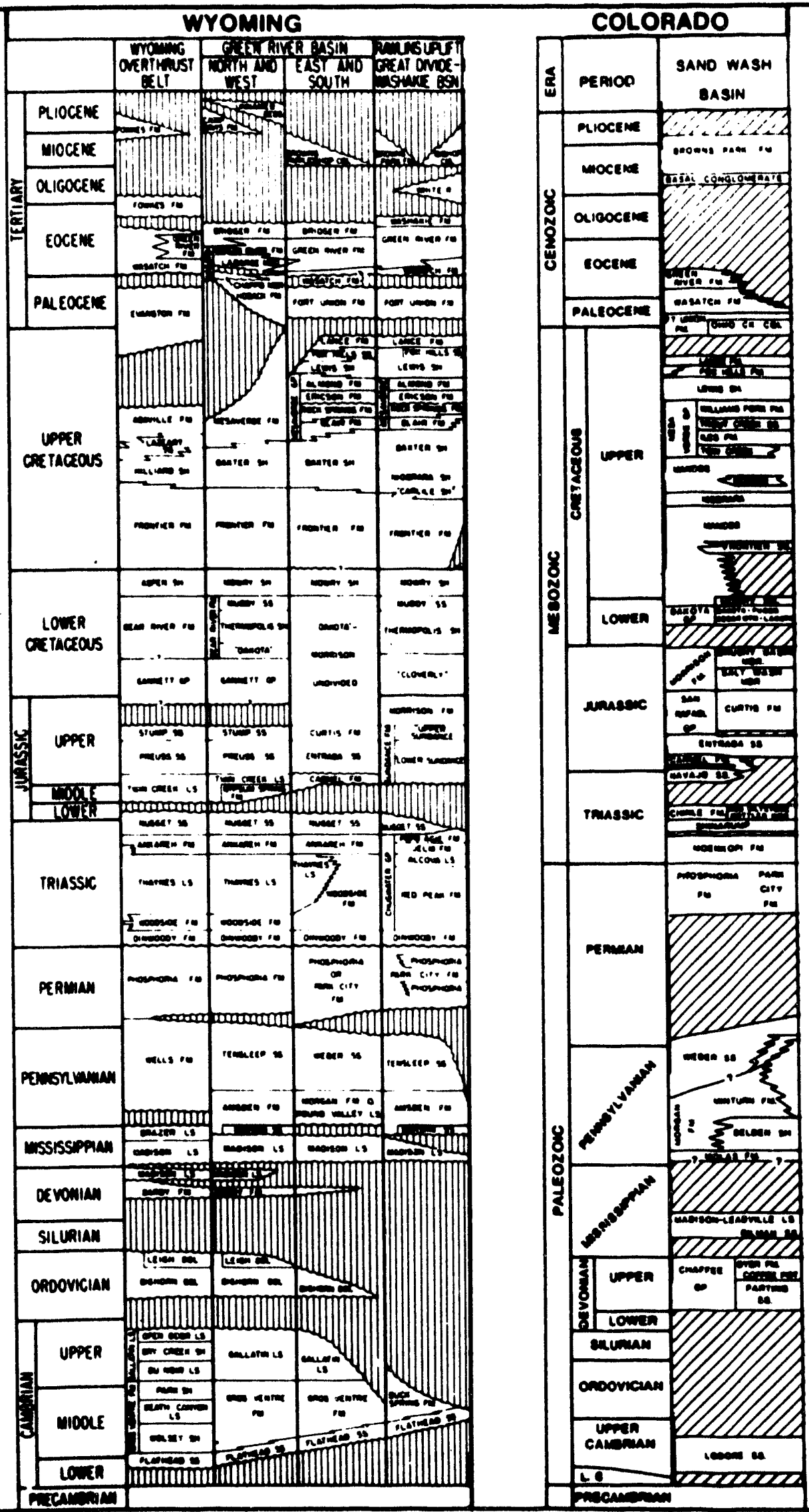

Figure 3. Generalized Stratigraphic Column of the Greater Green River Basin (after McCord, 1984). 
which resulted in the development of littoral sandbars and shallow waters. Some basal units of the Mesaverde Group and the Lazeart Sandstone and Adaville Formation were deposited during this regressive cycle (McCord 1984).

During the regressive cycle of the Claggett, tectonic activity such as volcanic activity in Montana, uplift and batholithic emplacement caused an abundance of sedimentation to occur eastward. This resulted in the deposition of the Mesaverde Group Rock Springs Formation in southwestern Wyoming and the Mesaverde Group Iles and William Fork Formation in northwestern Colorado. These sediments represent a transition from marine deposition to continental deposition. Important coal seams are found as a result of this transition zone (McCord 1984).

The transgressive phase of the Bear Paw cycle resulted in the deposition of the Lewis Shale and the Mesaverde Group Ericson Sandstone and the Almond Formation of the Rock Springs area. In the Rock Springs coal field, the Almond formation is coal bearing (McCord 1984).

PALEOCENE ERA

The Laramide orogeny (mountain building by folding and thrusting) occurred during the Late Cretaceous and into the Eocene. During this period, the Greater Green River Coal Region was generally one large basin surrounded by areas of uplift. These uplift areas 
which include the western Wyoming Thrust Belt, the Wind River and Granite Mountains, the Sierra Madre and Rawlins Uplift and the Unita Mountains contributed great quantities of clastics to the basin (McCord 1984).

During the Paleocene Era, sedimentation from these uplift areas resulted in the deposition of the Hogback Formation in the north and western part of the Greater Green River Basin which is a sequence of sandstone, conglomerate, siltstone and shaley limestone. The Hogback formation ranges in thickness from 6,000 feet to a 8,000 feet. The Fort Union formation, the most dominant and extensive Paleocene unit in the region, was also deposited as a result of the abundant clastics during this time. This formation is composed of a thick sequence of sandstone, shale and coalbeds ranging in thickness from 2,000 to 6,000 feet (McCord 1984).

Massive amounts of clastics were washed out of the Rawlins and Sierra Madre Uplift into the Washakie and Sand Wash Basins during the Paleocene Era. Tributaries came together to form large rivers which flowed north to the Great Divide Basin. This lead to the deposition of sandstones, shales, lignites and coals which were formed in a variety of low and high energy depositional environments. Clastics from the Granite Mountains and Sweetwater Uplift traveled south into the great Divide Basin and the Rock Springs Uplift. area. The extensive channel systems and thick sequences of coalbeds found in this area suggests that slow subsidence and low gradients gave way to extensive flood plains and 
swamps. These thick coalbeds can be seen in the Fort Union Formation at the north end of the Rock Springs Uplift (McCord 1984).

The Fort Union Formation in the northern portion of the Green River Basin, however, is made up primarily of a sandstone facies which indicates a high energy depositional environment. Coals and lignites are found in the southern portion of the Green River Basin which were deposited under a variety of swamp, lake and river environments. However these sediments are not as abundant as those found in the Rock Springs Uplift area (McCord 1984).

\section{EOCENE EKA}

Prior to uplift which divided the greater Green River Coal Region into separate basins, the Eocene sediments were deposited as one continuous unit. These units include the Wasatch, Green River and the Bridger formations. The Wasatch Formation is composed of a red bed which was deposited in subsiding basins of the southwestern portion of Wyoming (McCord, 1984).

The Green River Formation was formed by a lacustrine (lake) environment and intertongues with the Wasatch Formation. Specifically, the Green River Formation is a result of the cyclic rise and fall of lake Gosiute. This lake of Eocene age at its highest stand covered an area of approximately $39,000 \mathrm{~km}^{2}$, and at its lowest about $3,900 \mathrm{~km}^{2}$ (Eugster 
and Surdam 1973). The Green River Formation which was formed as a result of Lake Gosiute has a somewhat lenticular shape and is composed primarily of calcareous sedimentary rock. This formation is underlain by the Wasatch Formation and overlain by the Bridger Formation. The growth and shrinkage of the lake caused the interfingering of the Green River Formation and both the Wasatch and Bridger formations. At the margins of the Green River Formation, the Bridger formation lies directly on the Wasatch.

Three major stratigraphic units, the Tipton Shale Member, the Wilkins Peak Member, and the Laney Shale Member make up the Green River Formation. The Eocene Green River Formation is perhaps the most famous accumulation of lacustrine sediments in the world because it contains enormous deposits of oil shale and trona (Eugster and Surdam 1973).

The Bridger Formation is relatively widespread and can be seen in the Green River Basin, the Washakie Basin, portions of the Sand Wash basin and in the Unita thrust. The Bridger Formation marks a return to the depositional environment seen in the Wasatch Formation, although without the red coloration. The Bridger is probably best known for its high ash content (up to 20\%) and the badlands created by erosion of the formation at outcrops (McCord 1984). 


\section{OLIGOCENE, MIOCENE, PLIOCENE AND PLEISTOCENE ERAS}

Oligocene rocks are most prominent in central and southeastern Wyoming but almost nonexistent in the Greater Green River Basin area. Miocene and Pliocene rocks are found locally throughout the state but also are not of any significance in the Greater Green River Basin. Alpine glaciation occurred during the Pleistocene epoch. The present day features of the Greater Green River Basin and associated mountains and uplifts were carved by this glaciation along with deposition of outwash material. Since that time, the Greater Green River Basin has been subject to erosion of primarily wind and water mechanisms.

\section{COAL AND COALBED METHANE - OCCURRENCE, OUANTITY IN-PLACE AND CHEMICAL CHARACTERISTICS}

\section{COAL OCCURRENCE AND ESTIMATED COAL IN PLACE}

The Greater Green River Coal Region is located in southwestern Wyoming and northwestern Colorado. It encompasses an area of approximately 21,000 square miles. The coal age for the basin is of late Cretaceous and early Tertiary. Table 1 shows the general characteristics of coal in the region.

Important factors determining the regional character of the Greater Green River Basin is its depositional environment; the mainly fresh water swamps and flood plains along 


\begin{tabular}{|c|c|c|c|c|c|c|c|c|c|c|c|c|}
\hline \multirow{2}{*}{$\begin{array}{l}\text { Geographic } \\
\text { Area }\end{array}$} & \multirow[b]{2}{*}{ Rank' } & \multicolumn{3}{|c|}{ Bed Thickness (it) } & \multicolumn{2}{|c|}{ Moisture (\%) (AR) ${ }^{2}$} & \multicolumn{2}{|c|}{$\operatorname{Agh}(\%)(A B)^{2}$} & \multicolumn{2}{|c|}{ Suthur $(\% 6)^{2}$} & \multicolumn{2}{|c|}{$\begin{array}{l}\text { Hoating Velue } \\
\text { (Btu/b) }(A B)^{2}\end{array}$} \\
\hline & & Maximum & Range' & Average ${ }^{1}$ & Range & Average & Range & Averege & Range & Average & Range & Average \\
\hline Southern Wyoming & $\begin{array}{l}\text { Bituminous/ } \\
\text { Subbituminous }\end{array}$ & 50 & $4-35$ & $20^{\prime}$ & $10.2-20.5$ & 12.4 & $4.2-12.2$ & 7.1 & $.4-.9$ & .52 & $9,270-11.100$ & 10,500 \\
\hline Western Wyoming & $\begin{array}{l}\text { Bituminous/ } \\
\text { Subbituminous }\end{array}$ & 110 & $5-90$ & 16.5 & $20.4-20.9$ & 20.8 & $3.0-4.8$ & 4.5 & $.6-.7$ & 6 & $7.500-10,200$ & 9.600 \\
\hline Northwest Colorado & $\begin{array}{l}\text { Bituminous } \\
\text { Subbituminous }\end{array}$ & 42 & $6-13$ & 9.0 & $6.3-23.0$ & 16.1 & $3.9-13.8$ & 7.2 & $.2-2.7$ & .8 & $8.250-12.560$ & 10,330 \\
\hline
\end{tabular}

Table 1. General Characteristics of Coal in the Greater Green River Coal Region (after McCord, 1984). 
the nigrating margins of a shallow continental sea that repeatedly encroached on and retreated (transgressed and regressed) from a broad southwestern land mass (Choate et al.. 1984). It is because of these transgression and regression cycles and a relatively stable climate along with constant shoreline trends and a uniform source of sediment supply that coalbeds are present in the Greater Green River Basin. Figure 4 shows a general stratigraphic column of coal-bearing rocks in the region.

The Greater Green River Basin can be divided into two separate coal regions; the Green River Coal Region and the Hams Fork Coal Region.

\section{Green River Coal Region}

The Green River Coal Region of the Greater Green River Basin comprises an area of approximately 18,500 square miles and is the largest coal bearing area in the State of Wyoming. The principal coal-bearing formations in the Greater Green River Coal Region are the Wasatch, and Fort Union formations of Tertiary age and the formations of the Upper Cretaceous-age Mesa Verde Group. Coalbeds range in thickness from 1 to 20 feet and are consistently 5 to 10 feet thick. Coalbeds within the basin occur at outcrops down to 6,000 feet. Coal rank is sub-bituminous to high-volatile A bituminous (Boreck 1981, Bradley 1964, and McCord 1980). 


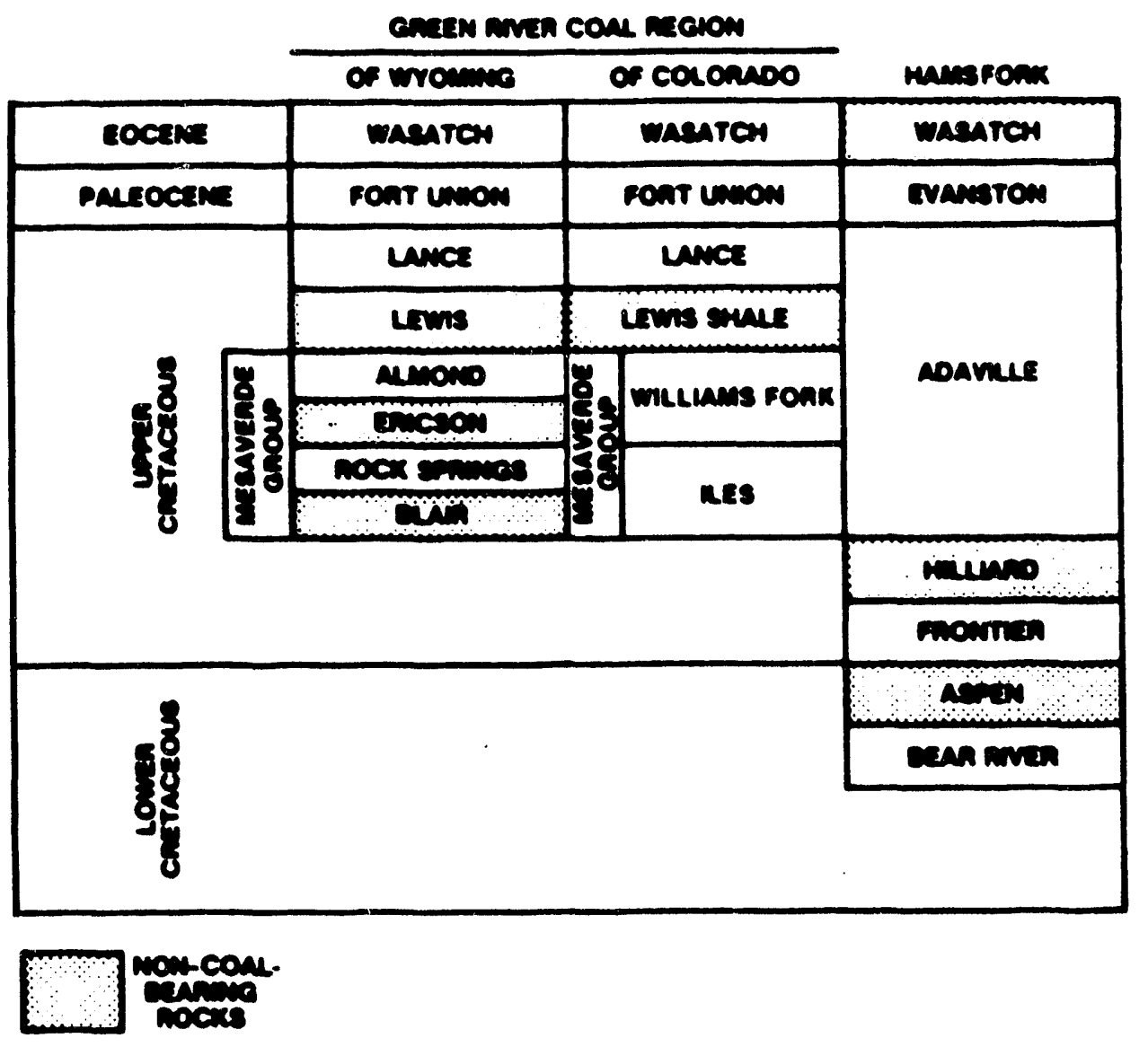

Figure 4. Coal Bearing Rocks of the Greater Green River Basin (anter McCord, 1984). 


\section{Hams Fork Coal Region}

The Hams Fork Coal Region is located on the western portion of the Greater Green River Basin and is rated as the fifth largest coal-producing area in Wyoming (Glass, 1977). The principal coal-bearing formations in the region are the Bear River Formation of Lower Cretaceous age; the Frontier, Blind Bull and Adaville formations of Upper Cretaceous age, and the Evanston formation of Paleocene age. The Frontier and Adaville formations are mined throughout the region while the Bear River, Blind Bull and Evanston formations are mined only locally (McCord 1984).

\section{GREATER GREEN RIVER SUBORDINATE BASINS}

The Greater Green River Basin is divided into four subordinate basins: the Green River Basin, the Great Divide Basin, the Washakie Basin, and the Sand Wash Basin. These subordinate basins contain similarities and differences from the standpoint of geology, coal occurrence, coal and coalbed methane production formations. The following is a brief discussion of the coal occurrence of each basin.

\section{GREEN RIVER BASIN}

The Green River Basin is located in the western half of the Greater Green River Basin. The most important coals occur in the Frontier Formation and the Mesaverde 
Equivalent Adaville formations, both of which are of Upper Cretaceous age. The Frontier Formation coals are high-volatile bituminous and the Adaville coals area sub-bituminous (GRI, 3-90).

\section{Great Divide Basin}

The principal coal-bearing formations of the Great Divide Basin are the Cretaceousage Rock Springs and Almond formations of the Mesaverde Group and the Lance Formation and the Fort Union and Wasatch formations of Tertiary age. The Cretaceous coals rank from high-volatile $\mathrm{C}$ bituminous to sub-bituminous $\mathrm{C}$ in the Mesaverde Group and Lance Formation while the Tertiary coals are sub-bituminous in rank (GRI, 3-90).

\section{Washakie Basin}

The principal coal-bearing formations of the eastern basin margin of the Washakie Basin are the Upper Cretaceous age Iles and Williams Fork formations of the Mesaverde Group and the Lance Formation of Tertiary age (GRI, 2-90).

\section{Sand Wash Basin}

The principal coal-bearing formations of the Sand Wash Basin are the Upper Cretaceous age Iles and Williams Fork formations of the Mesa Verde Group and the Lance 
Formation of Tertiary age. The Iles Formation is the base of the Mesaverde Group in the basin and rests conformably on the Moncos Shale. The Iles is the first progradation sequence or the first eastward advance of the Mesaverde shoreline. In the Sand Wash Basin, extensive coal mining has taken place in the Yampa field located in the southern margin of the basin. Bituminous and sub-bituminous coals have been mined from this field. The Mesaverde coals of the basin range from anthracite to semi-anthracite to noncoking (insufficient carbon percentage) and is ranked at high volatile $\mathbf{C}$ bituminous. Younger coals are usually sub-bituminous B and C (GRI, 3-90).

\section{Estimated Coal in Place and Chemical Characteristics}

The coal resources for bituminous coal to a depth of 3,000 feet for the Green River Coal Region is estimated at 49.0 billion tons while the Hams Fork Region has an estimated coal resource of 3.2 billion tons. The thickest coal seams in the b.sin are located in the eastern basins, are from 15 to 35 feet thick and are found in the Ft. Union and Wasatch formations. Cumulative net coal thicknesses in the Greater Green River Basin range from 150 to 200 feet thick. The typical thickness of the coal bearing intervals in the basin are 4,000 to 9,000 feet. Coal occurs to depths of 12,000 feet and coal seam orientation is north-northeast (Kaiser, et al. 1992). 
COALBED METHANE OCCURRENCE

Methane associated with coalbeds is a widespread occurrence in Wyoming (Jones et al. 1990). Although many geologic factors act in concert to determine the availability and producibility of coalbed methane, the sedimentary depositional system that hosts the coal seams and the fractures and fault within the coal are of primary importance in determining resources and recoverability, respectively (Ayers et al. 1988). The Greater Green River Basin Coal Region has the potential of being one of the leader in coalbed methane production in the United States because of the size of the coal region, the widespread occurrence of coal, the relatively high permeability and cumulative thickness of the coalbeds (Ambrose et al, 1992).

\section{Coalbed Methane Generation}

The generation of coalbed methane during the coalification process in the Greater Green River Basin area is assumed to be due to the burial of organic matter at increased depths associated with increased temperatures. The total heat exposure is dependent upon the time and depth of burial relationship. On a local scale, the introduction of igneous bodies can be seen causing heating and cooling at a very high rate which in turn speeds up the maturation cycle. Coalbed methane in the Greater Green River Basin area is primarily of biogenic origin with some migrated thermogenic coalbed methane (Paul et al. 1992). 
Other major factors involved in the study of the methane producing formation of the Greater Green River Basin are the history of the sedimentation process and the source material for deposition in the basin, interstratification of the marine and non-marine depositional environments and their relationship to each other and, as mentioned above, the heat, time and maturation cycle of deposition (Choate et al. 1984).

\section{Biogenic and Thermogenic Coalbed Methane Generation}

Coalbed methane is a natural by-product of the coalification (thermal maturation) of humic materials (derived from woody terrestial plants) that contain Type III vitrinic kerogen (Jones et al, 1990). Through time and increased temperature, volatile matter is driven off during coalification of humic material. Methane, water, carbon dioxide and nitrogen are components of this volatile matter.

During the early stages of coalification of buried peat, biogenic nethane is generated as a by-product of bacteria respiration (Jones et al. 1990). Organic material which developed from the swamps and marshes of the marine environments is the source material for the coalbeds and coalbed methane. After burial, if any sulfate is present in the coal formation, anaerobic bacteria consume all of the sulfate before methane generation can dominate. In environments of low sodium content, methane production begins immediately after the oxygen has been depleted (Rice and Claypool 1981). Aerobic bacteria metabolizes the oxygen present in both the organic material comprising the coalbeds and in the non- 
marine strata associated with the coalbeds. The aerobic bacteria produces carbon dioxide as a by-product which is consumed by anaerobic bacteria which in turn, produce biogenic methane gas. Given an appropriate amount of time and temperatures exceeding 50 degrees centigrade, most of the biogenic methane are produced (Jones et al. 1990).

As the depth of burial increases or the geothermal gradient increases, the temperatures exceed 50 degrees Centigrade generating additional water along with carbon dioxide and nitrogen. Once the temperatures exceed 120 degrees Centigrade, thermogenic methane is produced. The maximum generation of thermogenic methane from coal occurs at approximately 150 degrees centigrade. Methane is still generated at higher temperatures but at lower rates and volumes (Jones et al. 1990).

\section{Cleat Porosity and Permeability}

In order to better understand the rates of coalbed methane production, it is necessary to have an understanding of cleat fractures and cleat porosity of the formations. Natural fractures or cleats enhance the flow of both methane gases and fluids through formations. Cleats are systematic natural fractures in coal that are analogous to joints on other sedimentary rock (Raistrick and Marshall 1939; Ver Steeg 1942; McCulloch et al. 1974). Cleats are subdivided into two groups, face cleats and butt cleats. Face cleats are natural fractures in coal and are straight, and the longest, most persistent of the fractures in the coal. Butt cleats are shorter and perpendicular to face cleats, often curvilinear, and they 
terminate against the older face cleats. The tectonic forces controlling cleats is generally the same as that controlling jointing/fracturing in the surrounding rocks. However, due to differences in the time of induration of various sediments, for example coals versus sandstones, variations in the orientation of coal cleats and those of fractures in the surrounding rocks may be different if the tectonic stresses have varied throughout time.

The spacing of the cleats is dependent on the thickness of the coal seam, cleat height and the rank of the coal. A direct relationship exists between cleat spacing to bed thickness and cleat height while the relationship is inverse to coal rank.

Cleats are important conduits for the production of natural gas. The cleat porosity in many areas the cleats are initially filled with high percentages of connate waters and have a minimum gas saturation. Gas is held, absorbed onto the small interstitial surfaces within the matrix of the coal and only released when the hydrostatic pressure on the coal is lowered sufficiently to allow the desorption and mobilization of the majority of the sorped gas through the cleat porosity. The rate of desorption is an important factor in the production of gas from the formation and in particular in the earliest stages of production during which high rates of water production occur as the cleats release the connate waters first.

Face Cleats found in the Greater Green River Basin are oriented primarily northnortheast and east-northeast (Paul 1992). 
Coalbed Methane Production

The principal methane production horizons for the Greater Green River Basin occur in the lower Tertiary and the Upper Cretaceous. The lower Tertiary depositional environment was dominated by meandering stream deposits, lacustrine deposits and deltas which were sites of organic accumulation. The Upper Cretaceous depositional environment, however, was dominated by wave controlled migrating strand lines, deltas and barrier islands. The thickest Upper Cretaceous coal seams were preserved landward of and parallel to the paleoshoreline (Kaiser, et al 1992). Typically, the Upper Cretaceous coal seems rest on marine shoreline sandstones.

The principal target formations for coalbed menthane production in the Greater Green River Basin are the Mesaverde Group of Cretaceous age and the Fort Union and Wasatch formations of Tertiary age. Table 2 shows a summary of coalbed methane drilling and testing in the Greater Green River Basin from October through December of 1989 (GRI, 12-90). With only about 55 coalbed methane wells drilled during the past four years, the Greater Green River Basin region remains a largely untested frontier province for coalbed methane. Over 200 additional wells were permitted during 1991 and 1992, but most projects were significantly scaled down as a result of depressed natural gas prices, discouraging initial results, and unresolved environmental issues (GRI, 12-90). Many large scale projects are currently on hold due to concerns by Indian tribes that some locations for extensive future drilling operations are considered spiritual areas. The BLM and the State 


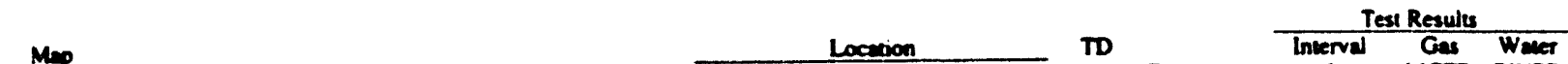

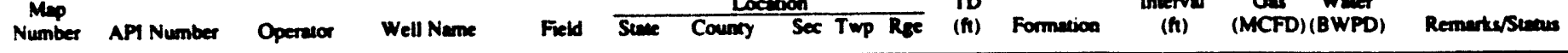

SAND WASH BASN, COLORADO AND WYOMING:

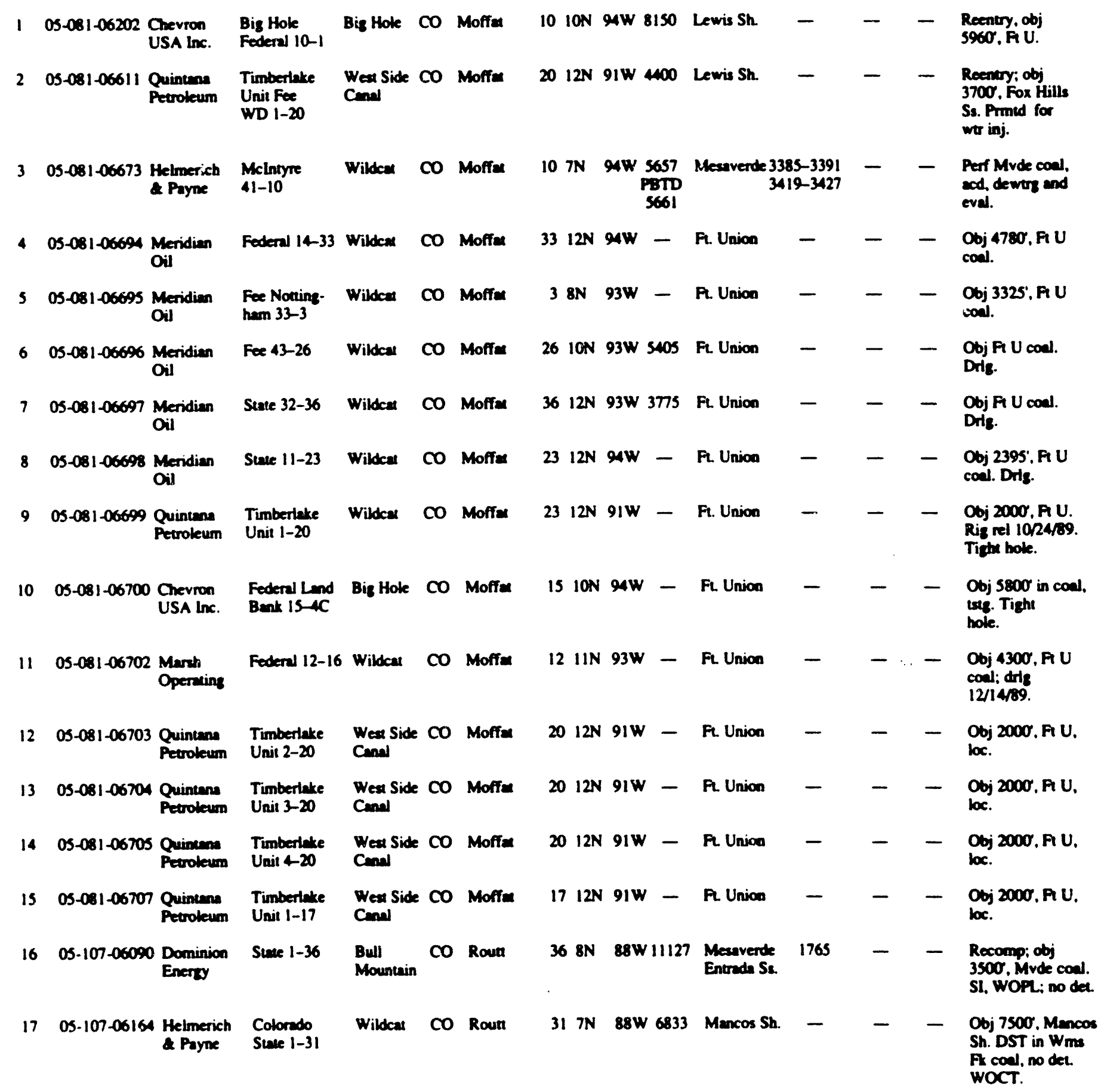

18 0S-037-20129 Jact Grynbers Wildea WY Sweerwer 21 12N 100 W 4706 Lewis Sh. - - - Reentry: obj Lewis Grynbere Federal 1-20 Sh: prod GW in $P$
U

Table 2. Summary of Coalbed Methane Drilling in the Greater Green River basin, October through December 1989 (after GRI, July 1990). 


\begin{tabular}{|c|c|c|c|c|c|c|c|c|c|c|c|c|c|}
\hline \multirow{3}{*}{$\begin{array}{c}\text { Map } \\
\text { Number }\end{array}$} & \multirow[b]{3}{*}{ API Number } & \multirow[b]{3}{*}{ Operator } & \multirow[b]{3}{*}{ Well Name } & \multirow[b]{3}{*}{ Field } & \multirow{2}{*}{\multicolumn{4}{|c|}{ Location }} & \multirow{3}{*}{$\begin{array}{l}\text { TD } \\
\text { (fi) }\end{array}$} & \multirow[b]{3}{*}{ Formation } & \multicolumn{2}{|c|}{ Text Resulfs } & \multirow[b]{3}{*}{ Remarks/Stalus } \\
\hline & & & & & & & & & & & Inierval & Ges Water & \\
\hline & & & & & State & County Sec: & $T w p$ & Rge & & & & (MCFD)(BWPD) & \\
\hline
\end{tabular}

GREAT DIVIDE Basin, WYOMING:

\begin{tabular}{|c|c|c|c|c|c|c|c|c|c|c|c|c|}
\hline- & $49-037-22663$ & $\begin{array}{l}\text { Buttonwood } \\
\text { Petroleum }\end{array}$ & $\begin{array}{l}\text { Federal } \\
1-2-32\end{array}$ & Wildcat & WY & Sweetwater $3223 \mathrm{~N} 102 \mathrm{~W}$ & - & Mesaverde & - & - & - & $\begin{array}{l}\text { Obj } 4200^{\prime}, \text { Rock } \\
\text { Spgs Fm. }\end{array}$ \\
\hline- & $49-037.22664$ & $\begin{array}{l}\text { Buttonwood } \\
\text { Petroleum }\end{array}$ & $\begin{array}{l}\text { Federal } \\
1-1-22\end{array}$ & Wildcat & WY & Sweetwater 22 22N 102 W & 一 & Mesaverde & - & - & - & $\begin{array}{l}\text { Obj } 3460^{\prime} \text {. Blair } \\
\text { Fm. }\end{array}$ \\
\hline - & $49-037.22666$ & $\begin{array}{l}\text { Triton Oil } \\
\text { and Gas }\end{array}$ & UPRC I & Wildcat & WY & Sweetwater $922 \mathrm{~N} 102 \mathrm{~W}$ & 4000 & Mesaverde & - & - & - & $\begin{array}{l}\text { Mrde obj; cnd } \\
\text { coul for dspn: } \\
\text { tsed. SI. }\end{array}$ \\
\hline- & 49.037 .22667 & $\begin{array}{l}\text { Triton Oil } \\
\text { and Gas }\end{array}$ & UPRC 2 & Wildcat & WY & Sweetwater I $22 \mathrm{~N} 102 \mathrm{~W}$ & 4000 & Mesaverde & - & 80 & 400 & $\begin{array}{l}\text { Perf } 2 \text { Mvde cosl } \\
\text { intr; Is net hrb- } \\
\text { mvb coel. } \\
\text { Dewtrg, pinpd } \\
\text { signif } \mathrm{CO}_{2} \text {. }\end{array}$ \\
\hline - & $49-037.22681$ & $\begin{array}{l}\text { Chevron } \\
\text { USA Inc. }\end{array}$ & $\begin{array}{l}\text { Chevron } \\
\text { Federal I-6 }\end{array}$ & Wildcat & WY & Sweetwater $621 \mathrm{~N} 96 \mathrm{~W}$ & - & FL Union & $3785-3957$ & - & 一 & $\begin{array}{l}\text { Obj } 4100 \text {. Fi U } \\
\text { coul. Crd intr. } \\
\text { PeA. }\end{array}$ \\
\hline - & 49-035-21008 & $\begin{array}{l}\text { Prima Oil } \\
\text { and Gas }\end{array}$ & $\begin{array}{l}\text { Springman } \\
\text { Creek Unit }\end{array}$ & Wildcat & WY & $2230 \mathrm{~N} / 14 \mathrm{~W}$ & 4150 & Mesaverde & 一 & - & - & $\begin{array}{l}\text { Drid } 11 / 30 / 89 . \\
\text { Tight hole. }\end{array}$ \\
\hline- & $49-037-22708$ & $\begin{array}{l}\text { Eagle Oil } \\
\text { and Gas }\end{array}$ & $\begin{array}{l}\text { UPRC } \\
1-29\end{array}$ & Wildcat & WY & Sweetwater $2922 \mathrm{~N} 104 \mathrm{~W}$ & - & Blair & - & - & - & $\begin{array}{l}\text { Obj } 6000 \text {, Blair } \\
\text { Fm. Ping to tst } \\
\text { Cret \& Tent } \\
\text { coals. }\end{array}$ \\
\hline- & $49-037-22709$ & $\begin{array}{l}\text { Eagle Oil } \\
\text { and Gas }\end{array}$ & $\begin{array}{l}\text { UPRC } \\
|-2|\end{array}$ & Wildcat & WY & Sweetwater $2122 \mathrm{~N} 104 \mathrm{~W}$ & 一 & Blzir & $\rightarrow$ & - & - & $\begin{array}{l}\text { Obj 6000". Blair } \\
\text { Fm. Ping to tst } \\
\text { Cret \& Tent } \\
\text { coals. }\end{array}$ \\
\hline
\end{tabular}

Table 2. Summary of Coalbed Methane Drilling in the Greater Green River basin, (cont'd) October through December 1989 (after GRI, July 1990). 
of Wyoming recommended that further environmental studies be performed in these areas of Spiritual importance to the Indians prior to any exploration for methane gas.

Coalbed methane exploration has concentrated on the Sand Wash Basin and the Rock Springs Uplift of the Greater Green River Basin. The Dixon field operated by Fuelco is the only commercial production currently taking place within the Greater Green River Basin. Many companies with previous activities within the basin have since abandoned operations.

As mentioned above, Fuelco is the only company in the Greater Green River Basin which is producing coalbed methane commercially. Completions in the Dixon field Almond Formation of the Mesaverde Group in the Sand Wash Basin are exhibiting average gas production of 15 MCFD. All of the wells were hydraulically stimulated with four of these wells exhibiting an average production rate of 50 MCFD. The best well in the Dixon field produced an average of 60 MCFD during 1991 and 1992 and peaked at 100 MCFD. Preliminary tests indicated the formations in this area were undersaturated in methane gas which means that substantial pressure reduction will be required to initiate gas desorption (removal of absorbed material) (GRI, 8-93).

A substantial amount of water is being produced from the Dixon field: 500 to 600 BPD per well for the life of the well. The field itself produced 3,000 BPD in May 1993. Fuelco has determined that the water is originating from relatively high permeable coals 
themselves, eliminating the ability to complete select zones in order to reduce water production. The water of these formations exhibits an average total dissolved solids content of 1,800 parts per million (ppm) and is currently being discharged onto the ground under an NPDES permit (GRI, 8-93).

Cockrell Oil Corporation abandoned a 16 well coalbed methane project in the Craig Dome field which produced over 2 million barrels of water and no sustained gas during 1990 through 1992. Water production rates over a one year pump test period for this field averaged 518 barrels per day (BPD) per well (GRI, 8-93).

Given these setbacks, a limited amount of methane gas is currently being produced from the Greater Green River Basin. However, operators continue to be optimistic about the future potential of the basin for gas production from the standpoint of total recoverable gas in place.

\section{HYDROLOGY}

General information available on the hydrology of the Greater Green River Basin had been prepared by the United States Geological Survey in Regional Aquifer Systems Analysis (RASA). The available hydrologic information on the basin includes general geohydrology and reservoir characteristics for the area of the Upper Colorado River Basin. This area encompasses data from parts of Colorado, Arizona, Utah and Wyoming. Specific 
hydrologic information was reviewed on the pre-Tertiary aquifers on this regional basis but only on a limited basis for the area of the Greater Green River Basin. Other sources of hydrogeologic information were utilized for the Tertiary aquifers and as a supplement to the RASA.

\section{AQUIFER AND RESERVOIR DISTRIBUTION}

Groundwater in the Greater Green Riyer Basin ranges in quality from fresh to brine. Fresh water is known to occur primarily in the upper alluvium, shallow Tertiary rocks and near the outcrop of any deeper aquifers. These outcrops are found in the uplifted area surrounding the subordinate basins. The fresh water found at the outcrops represents meteoric recharge to these deeper, poorer quality aquifers.

Approximately one-half of the public supply of water in the Greater Green River Basin Area comes from surface water sources. Groundwater is commonly used for irrigation.

\section{PALEOZOIC AQUIFERS}

The approximately 8,400 foot thick Paleozoic section contains 27 rock units. These 27 rock units have been divided into 11 hydrostratigraphic units. The term hydrostatic unit includes aquifers and confining zones. Aquifers have been subdivided into those which are 
of regional nature and those which appear to be more localized. The regional aquifers include the Mississippian-Devonian carbonates and the Permo-Pennsylvanian sandstones. Local aquifers include the basal Cambrian sandstones, Cambro-Ordovician rocks, Mississippian carbonate and clastic rocks and Permo-Pennsylvanian evaporites. All of the Paleozoic section is capped by another confining zone of Triassic age, the Moenkopi Formation. (Geldon 1986)

\section{Mississippian-Devonian Carbonate Aquifer}

The Mississippian-Devonian aquifer is the most productive of the aquifers and yielded the largest flows of groundwater to wells and springs in the area. The unit consists of the Devonian-age Dyer Dolomite and the Mississippian-age Leadville Limestone. Core measurements of porosity from this unit show values from 0.1 to 21 percent. Hydraulic conductivities from well tests indicate values of 0.0001 to 0.1 feet per day (fpd) in the basin area. Hydraulic conductivities are much higher in the uplift areas and where the units are exposed owing to secondary porosity from tectonic deformations and the release of overburden pressure. Transmissivity for the Mississippian-Devonian carbonate aquifer in the basin area ranges from 0.1 to 1000 feet squared per day ( $\mathrm{ft}^{2} \mathrm{pd}$ ) (Geldon, 1986). 


\section{Permo-Pennsylvanian Sandstone Aquifer}

The Permo-Pennsylvanian sandstone aquifer is comprised entirely of the Weber Sandstone. This is the second most productive Paleozoic aquifer for the area. There are many springs in the Weber Sandstone at the outcrop. Springs in the area have yields of 10 to 270 gallons per minute. Drillstem test data indicate that flows of 1.4 to $89 \mathrm{gpm}$ can be expected from the Weber in the subsurface. From a total of 2,482 cores on the upper Colorado River Basin the porosity of the Weber varies from less than 0.11 to 27 percent with a medium value of 8 percent. Based on the thickness of the Weber the likely storage coefficient for the hydrostatic unit is $1 \times 10^{-4}$ to $5 \times 10^{-4}$ (Geldon, 1986).

\section{MESOZOIC AQUIFERS}

The USGS regional aquifer systems analysis for the Mesozoic rocks of the Upper Colorado River basin was used extensively for the characterization of these aquifers. (Freethey, 1991)

The Mesozoic has been divided into ten geohydraulic units. These ten units represent five aquifers and five confining zones. The five aquifers in stratigraphic order from oldest to youngest are the Navajo-Nugget aquifer, the Entrada-Preuss aquifer, the Morrison aquifer, the Dakota aquifer and the Mesaverde aquifer (Freethey, 1991). 


\section{Navajo - Nugget Aquifer}

The Navajo-Nugget Aquifer is composed of the Nugget, Glen Canyon and Page Sandstones and the Glen Canyon Group, which includes the Wingate Sandstone, the Moenave and Kayenta formations and the Navajo Sandstone. In the Greater Green River Basin, the aquifer occurrs in the Nugget Sandstone. This aquifer exhibits thicknesses of 1,000 feet in the Wyoming Thrust Belt and more than 1,500 feet on the southwestern flank of the Unita Mountains. The Navajo-Nugget was deposited under arid and terrestrial conditions and, therefore, are primarily eolian or fluvial in origin. Primarily, the saturated thickness of the aquifer in the greater Green River Basin is 500 to 1,000 feet; however, thickness of 1,000 to 2,000 feet are seen in the subordinate Green River Basin. (Figure 5) The Navajo-Nugget aquifer is found beneath the Carmel-Twin Creek confining unit. (Freethey, 1991)

The Navajo-Nugget aquifer exhibits hydraulic properties such as an air permeability of 900 millidarcies, a hydraulic conductivity of $1 \mathrm{fpd}$, storage coefficient of $8 \times 10^{-4}$ and effective porosity of 19 percent. (Freethey, 1991)

\section{Entrada-Preuss Aquifer}

The Entrada-Preuss Aquifer is composed of 75 to 100 percent cross bedded eolian sandstone. The aquifer is thickest in the west and thins eastward. The Entrada sandstone 


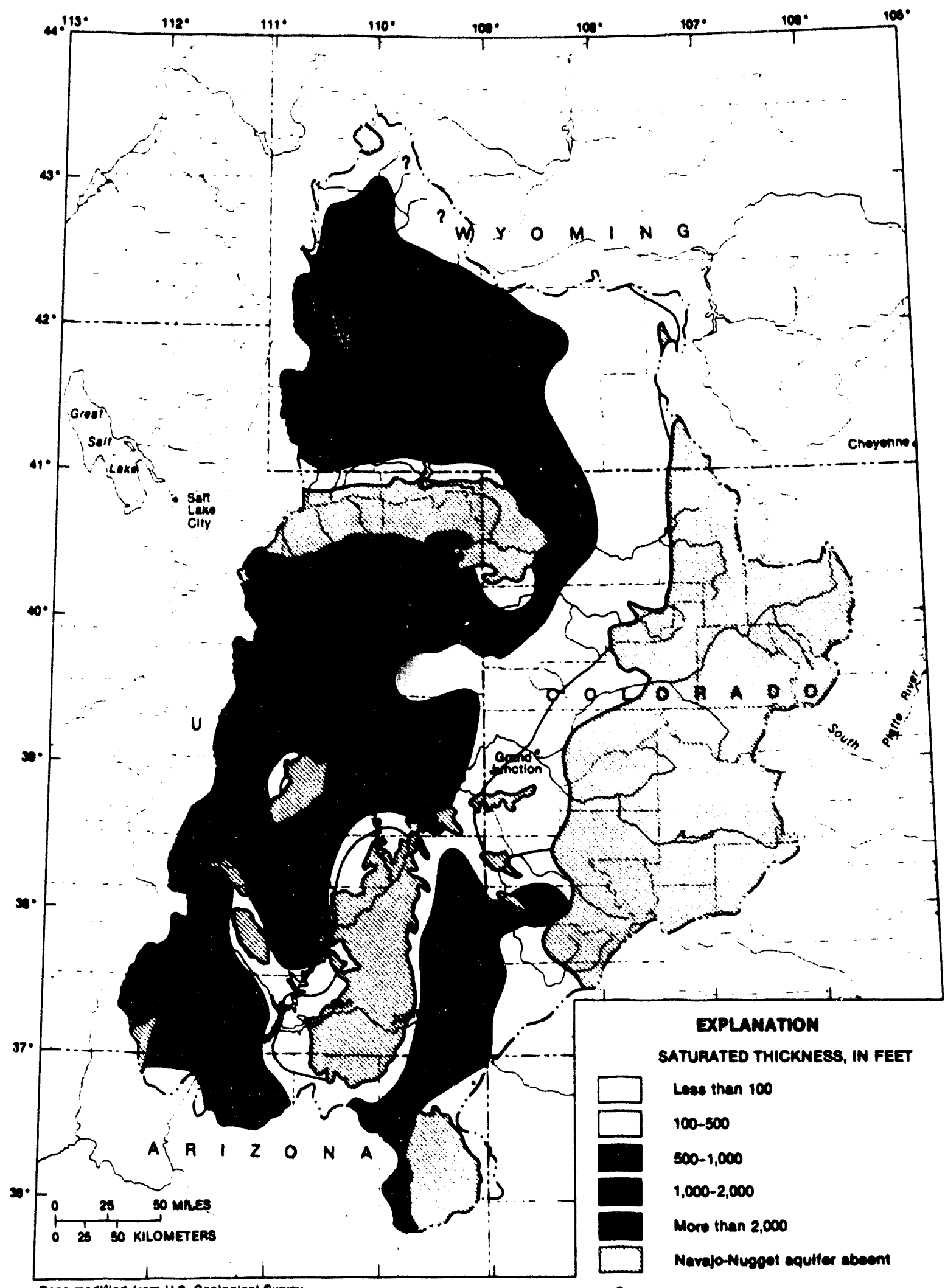

caes modified Irom U.S. Geological Survy

$?$ QUERIED WHERE OCCUARENCE UNCERTAN

Figure 5. Saturated Thickness of the Navajo-Nugget aquifer (after Freethey, 1991). 
in Utah grades into the Preuss sandstone in the western Unita Uplift and Wyoming Thrust Belt and the Lake Member of the Sundance Formation in western Wyoming (Imlay, 1952). The Entrada grades into the Canyon Springs sandstone member of the Sundance Formation in northwestern Colorado and southern Wyoming. The saturated thickness ranges from less than 100 feet in the eastern portion of the basin to 1,000 feet in the western portion of the basin. (Figure 6) (Freethey, 1991)

The average hydraulic characteristics of the Entrada aquifer are an air permeability of 600 millidarcies, hydraulic conductivity of 1 fpd, storativity of $4 \times 10-5$ and effective porosity of 13\% (Freethey, 1991).

\section{Morrison Aquifer}

The Morrison Aquifer consists of a number of sandstones within the Morrison formation. The sands represent fluvial processes of deposition under moderate climatic conditions. The extent of the Morrison aquifer is unknown in the Greater Green River Basin area; however, the fine-grained lithology of the Morrison Formation indicates that the presence of an extensive aquifer is unlikely (Freethey, 1991).

The average hydraulic characteristic of the Morrison Aquifer in the Lower Upper Colorado Basin are an air permeability of 300 millidarcies, a hydraulic conductivity of 1.6 fpd, a storage coefficient of $1 \times 10^{-4}$ and an effective porosity of 13 percent. 


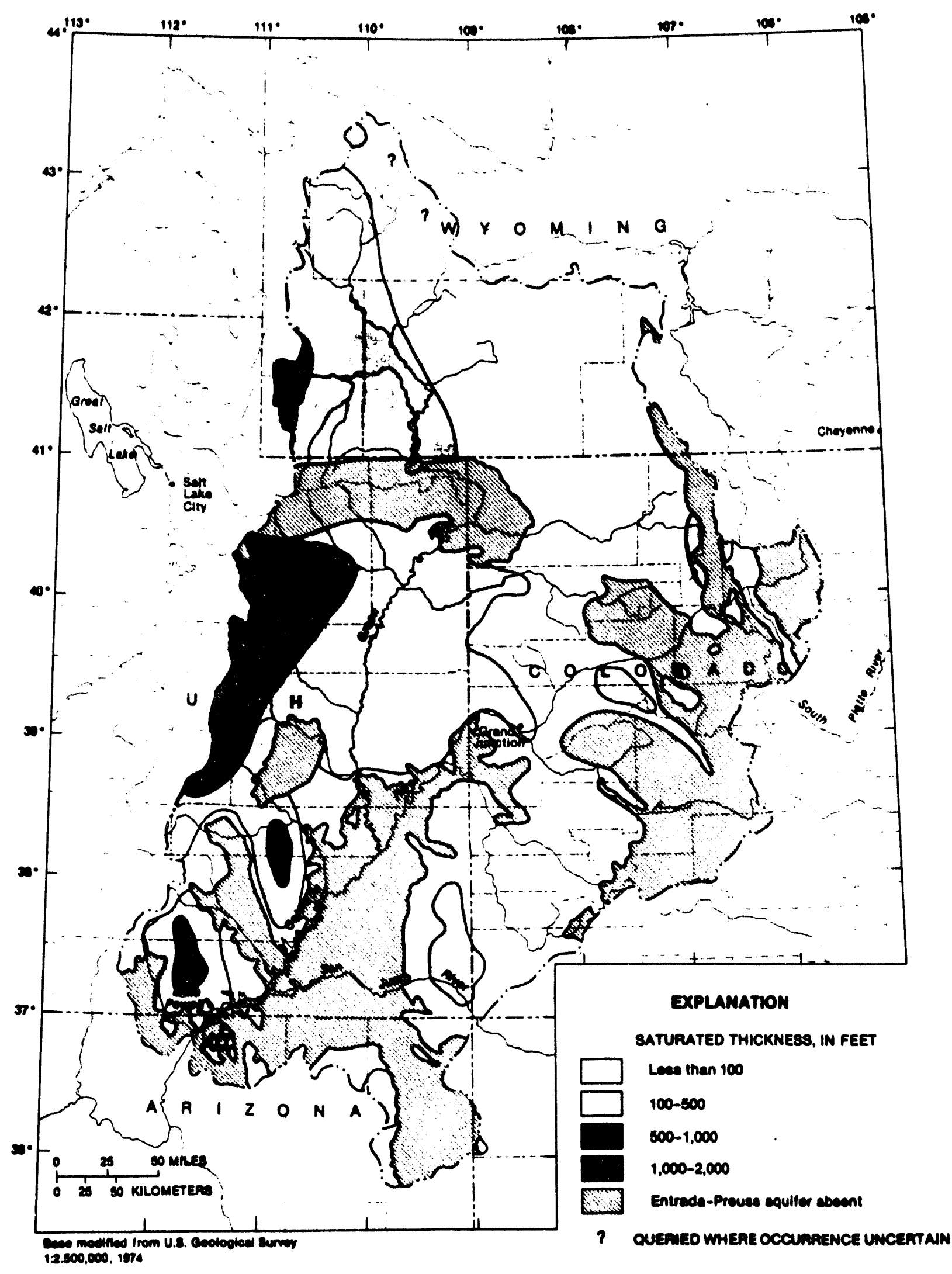

Figure 6. Saturated Thickness of the Entrada-Preuss Aquifer (after Freethey, 1991). 


\section{Dakota Aquifer}

The Dakota Aquifer consists in part of the Dakota Sandstone within the southeastern portion of the Greater Green River Basin. These units represent coastal plain clastic sediments along a transgressive sea. The saturated thickness of the unit is less than 100 feet in the majority of the study area. The aquifer is topped by the Mancos Confining Unit but is more than 1,000 feet thick in the Wyoming Thrust Belt (Figure 7) (Freethey, 1991).

The average hydraulic characteristics of the Dakota Aquifer are an air permeability of 40 millidarcies, a hydraulic conductivity of $0.25 \mathrm{ft}$. per day, a storage coefficient of 0.0001 and an effective porosity of 10 percent.

\section{Mesaverde Aquifer}

The Mesaverde Aquifer consists of a large number of stratigraphic units encompassing all of the Mesaverde Group, the upper portion of the underlying Mancos shale and, were preset, the overlying Lance Formation. The rocks represent transgressiveregressive sequences in complex vertical and lateral patterns of fluvial, deltaic, lagoonal, swampy and shallow marine deposition. The saturated thickness of the total Mesaverde Aquifer throughout most of the Greater Green River Basin is more than 2000 feet. (Figure 8) (Freethey, 1991). 


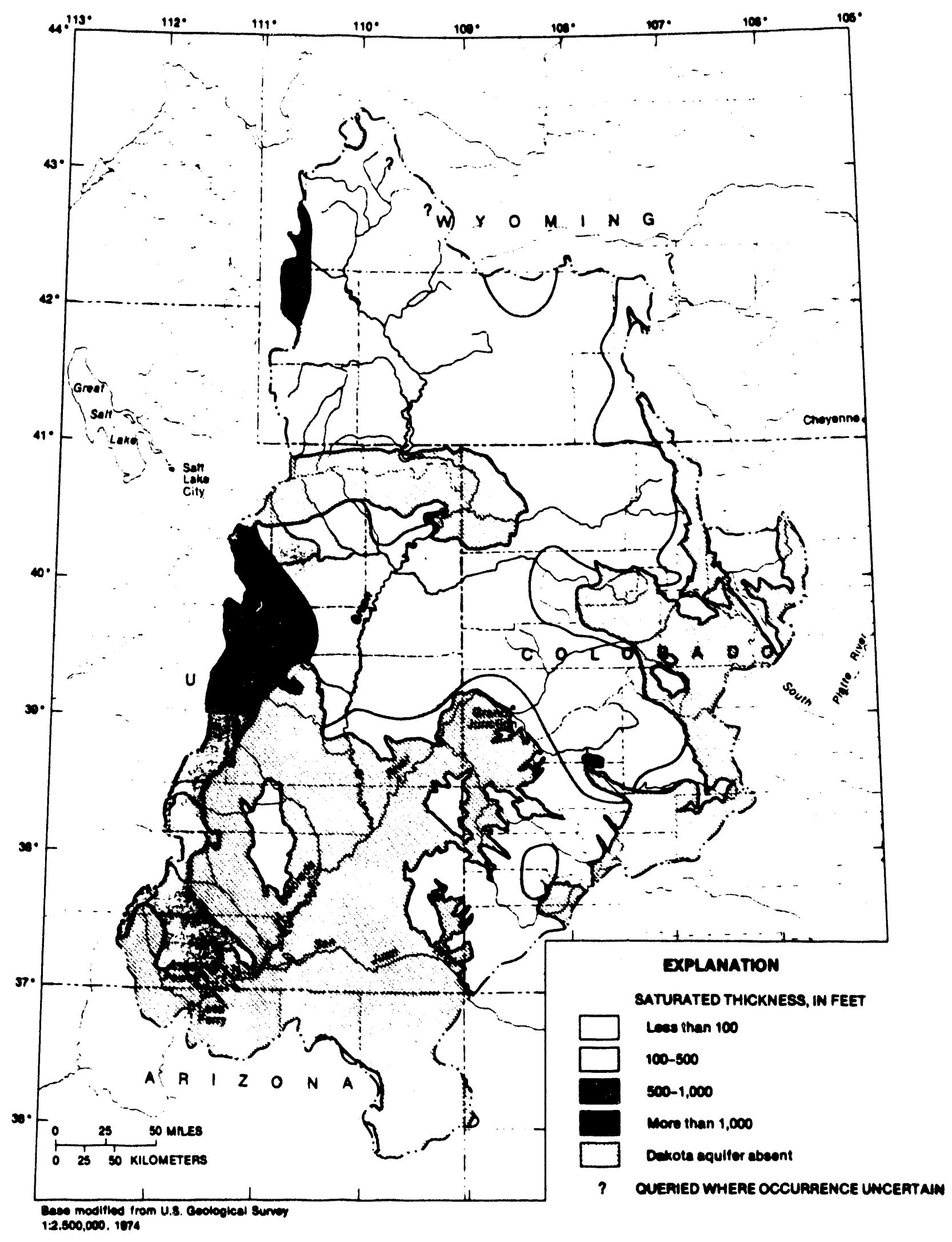

Figure 7. Saturated Thickness of the Dakota Aquifer (after Freethey, 1991). 


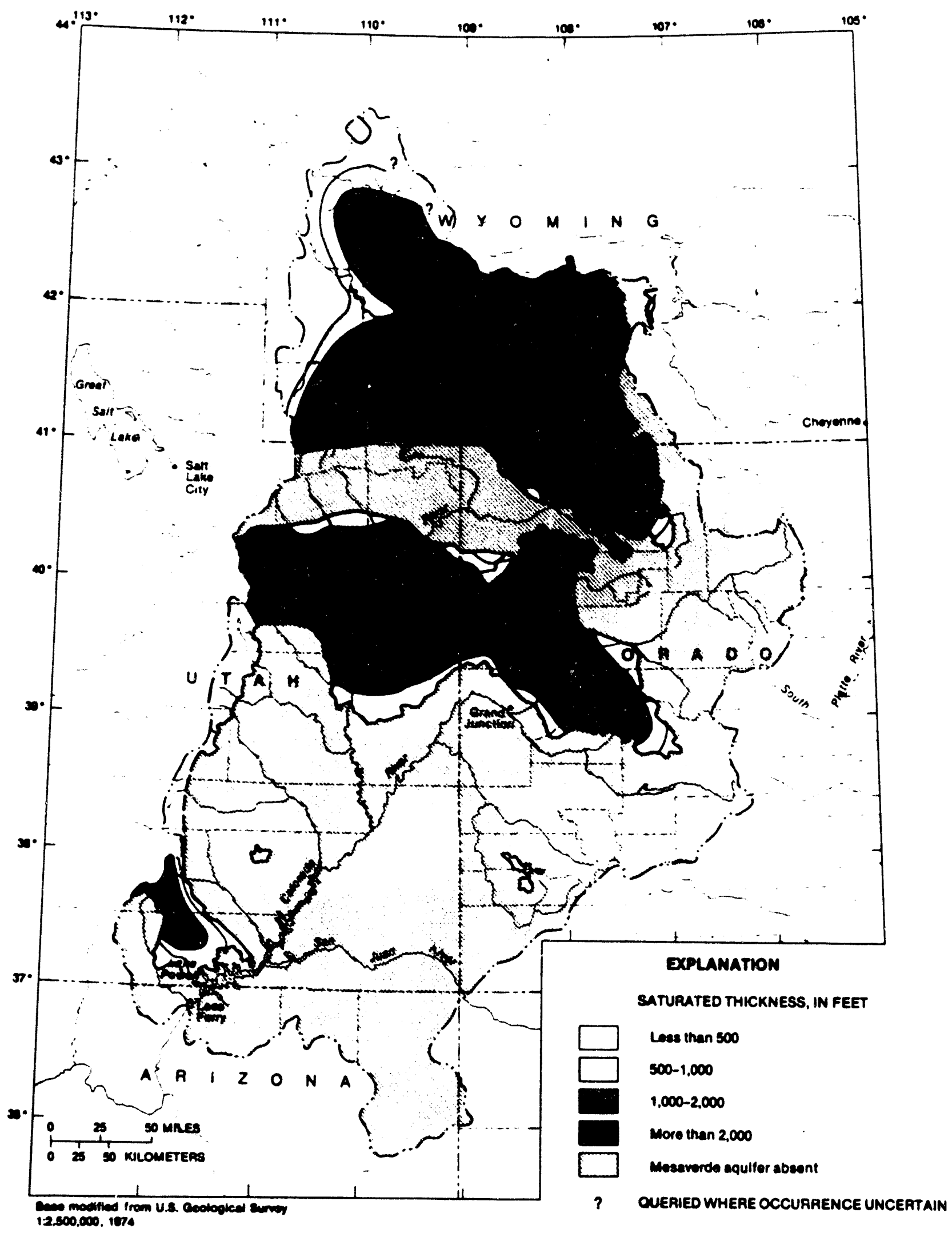

Figure 8. Saturated Thickness of the Mesaverde Aquifer (after Freethey, 1991). 
The average hydraulic characteristics of the Mesaverde Aquifer are an air permeability of 15 millidarcies, a hydraulic conductivity of $0.30 \mathrm{fpd}$, a storage coefficient of $4 \times 10^{-5}$ and an effective porosity of 11 percent (Freethey, 1991).

\section{CENOZOIC AQUIFERS}

The Wasatch Formation of lower Tertiary age yields water in the Greater Green River Basin. The Wasatch exhibits a realitively uniform hydraulic conductivity of $2 \mathrm{fpd}$ to a depth of 2,000 feet. However, the hydraulic low conductivity is much lower at 5,000 and 7,000 feet below the surface $\left(7 \times 10^{-3}\right.$ and $5 \times 10^{-4}$ fpd respectively). Recharge occurs at the periphery of the basins and in the upland areas. Groundwater discharges into the streams in the central portion of the basin (Taylor, et al, 1984).

\section{GROUNDWATER QUALITY AND RECHARGE TO AQUIFERS}

The groundwater of the Navajo-Nugget in the Greater Green River Basin is likely to be of a sodium chloride composition. Based on 289 analyses of the unit across the upper Colorado River Basin area, the total dissolved salt as concentration is approximately 11,800 ppm. Seventy-nine percent of this analysis is sodium chloride (Freethey, 1991). 
The groundwater quality of the Entrada is based on 64 analyses throughout the Upper Colorado River Basin. The total dissolved solids concentration of the water averages 13,500 parts per million (ppm) (Freethey, 1991).

The groundwater quality in the Morrison Aquifer, based upon the analysis of 105 samples, is a total dissolved solids content of approximately 10,000 parts per million (ppm) (Freethey, 1991).

The groundwater quality of the Dakota Aquifer based upon 113 analyses indicates an average total dissolved solids content of 4,500 parts per million (Freethey, 1991).

Based upon 538 analyses of the Mesaverde Aquifer in the Upper Colorado River Basin, the total dissolved solids concentration is about 7,500 parts per million (Freethey, 1991).

The groundwater quality in the upper aquifer of the Cenozoic generally degrades downgradient and with depth. The water is of sodium bicarbonate composition containing moderate amounts of sulfate and low concentrations of chloride and fluoride. The total dissolved solids concentration varies from 250 to more than $2,000 \mathrm{mg} / \mathrm{L}$. 
The groundwater quality in the lower aquifer is much poorer. High concentrations of easily evaporitic rock matrix material cause the water to commonly have a total dissolved solids concentration of $30,000 \mathrm{mg} / \mathrm{L}$. 


\section{RESEARCH LIMITATIONS}

Limited information was available in the literature for the specific objectives for which the research was conducted. Data limitations include the following:

Formation hydrology

Formation water qualities

Field completion and production data

Coalbed methane production information

Cleat porosity and permeability

\section{SUMMARY}

The Greater Green River Basin is a broad synclinal basin into which detritus material from surrounding uplifts and mountains were deposited. In addition, the basin includes the more geologically complexed Hams Fork Coal Region which is within the Wyoming Thrust belt located on the western side of the Greater Green River Basin. Folding, subsidence and uplift caused periodic transgression and regression cycles which produced a variety of both marine and non-marine deposition environments. Pressures, temperatures and time acted on these depositional sequences to produce coal and coalbed methane. The basin has significant reserves of gas in place estimated by the Department of energy (DOE) at between 1 and 30 trillion cubic feet (TCF) of coalbed methane (GRI). 
Development of this resource is limited by unpredictable reserves and often low rates of gas production. Associated sandstone production often finds limited reservoirs or water producing sands laterally to gas productive sands. Enhanced stimulation and production technology will need to be applied in order to bring about the successful development of these resources.

Production will be enhanced in areas of natural fracturing. These fractures will most likely be structurally induced both in anticlinal and synclinal situations. The synclinal areas will possibly contain greater amounts of water than those found on the anticlines.

Groundwater is known to occur in many of the coalbed methane producing formations of the Greater Green River Basin. The Greater Green River Basin is considered a good basin for the use of Jck McIntyre's patented tool due to the large amounts of poor quality water being produced from the coalbed methane wells in the area.

Low-rank coal with modest gas content and fresh water is encountered within the Green River Subordinate Basin. However, medium-volatile bituminous coals containing 400 TCF/ton of methane gas with associated saline water is known to exist in the steeply dipping flanks of the Rock Springs Uplift. In general, the water quality from the aquifers in the basin appears to be best in the upper formations and decrease in quality with depth. However, some fresh water aquifers are known to occur at depths where typical brackish and brine waters were expected. There is a direct relationship between the rate at which 
groundwater can be produced from these formations and the thickness of the aquifer, porosity, permeability, grain size, presence or lack of fractures and hydraulic continuity.

Historically, surface waters of the Greater Green River Basin area have been the primary source of water for public supply. These surface waters have been appropriated by the state and additional groundwater resources exploration are planned, at which time a better understanding of the availability and quality of groundwater in the basin can be determined. Gas well completion information on some areas of the Greater Green River Basin show high water production of primarily poor quality. This makes the basin a potential candidate for Jack McIntyres's patented tool.

\section{ACKNOWLEDGEMENT}

The author express thanks to the United States Department of Energy (DOE) for funding this work. The grant awarded to Jack W. McIntyre under DOE Contract No. DEFG46-92R699202. Mr. McIntyre contracted Geraghty \& Miller, Inc. to perform the research. Special thanks go to Anchor Holm, Robert Miller, Hugh Robotham and Sandra Elliott for editing and reviewing this paper. Thanks to Carol Ballard for the extensive word processing needed for this document. 


\section{DISCLAIMER}

Mention of specific brand names or models of equipment is for information only and does not imply endorsement of any particular brand. 


\section{REFERENCES}

Ambrose, W. A., Tyler, R, , Scott, A. R., and Kaiser, W. R., Coalbed Methane Potential of the Greater Green River, Piceance, Powder River, and Raton Basins, Bureau of Economic Geology, University of Texas at Austin, Austin, Texas, Abstract in, Association Round Table, The American Association of Petroleum Geologists Bulletin, p. 1255, 1992.

Anderman, G.C.,Subsurface Stratigraphy of the Pre-Niobrara Formation in the Green River Basin, Wyoming, in Wyoming Stratigraphy, Part I, Subsurface Stratigraphy of the Pre Niobrara Formation in Wyoming, Nomenclature Committee, Wyoming Geological Association, pp. 49-68, 1956.

Boreck, D.L., Tremain, C.M., Sitowitz, Linda, and Lorenson, T.D., Coalbed Methane Potential of the Sand Wash Basin Green River Coal Region, Colorado, Colorado Geological Survey Open-File Report 81-6, p. 25, 1981.

Bradley, W. H., Geology of the Green River Basin Formation and Associated Eocene Rocks in southwestern Wyoming and Adjacent Parts of Colorado and Utah, U.S. Geological Survey, Professional Paper 496-A, 1964.

Bradley, W.H., Geology of Green River Formation and Associated Eocene Rocks in Southwestern Wyoming and Adjacent Parts of Colorado and Utah, U.S. Geological Survey Professional Paper 496-A, p. 86, 1964.

Fidlar, M.M., Structural Features of the Green River Basin: Wyoming Geological Association Guidebook, 5th Annual Field Conference, 1950.

Freethey, Geoffrey W. and Cordy, Gail E., Geohydrology of Mesozoic Rocks in the Upper Colorado River Basin in Arizona, Colorado, New Mexico, Utah and Wyoming, Excluding the San Juan Basin, United States Geological Survey Professional Paper 1411-C, 1991.

Geldon, A.L.,"Hydrostratigraphic Characterization of Paleozoic Formations in Northwestern Colorado", New Interpretation of Northwest Colorado Geology, Rocky Mountain Association of Geologists, pp. 265-282, 1986.

Haun, J.D., Introduction of the Geology of Northwest Colorado, in Exploration for Oil and Gas in Northwestern Colorado, Rocky Mountain Association of Geologists, p 7-15, 1962.

Imlay, R.W., Marine Origin of Preuss Sandstone of Idaho, Wyoming and Utah, American Association of Petroleum Geologists Bulletin, v. 36, no. 9, p. 1735-1753, 1952. 
Jones, Richard W., DeBruin, Rodney H., Coalbed Methane in Wyoming, Public Information Circular No. 30, Laramie, Wyoming, 1990.

Lochman-Balk, C., Cambrian Stratigraphy of the South and West Margins of Green River Basin, in Guidebook, Tenth Annual Field Conference, Green River Basin, Wyoming Geological Association, pp 29-37, 1955.

McCord, J. P., Geologic Overview, Coal and Coalbed Methane Resources of the Greater Green River Coal Region, Wyoming and Colorado, in Rightmire, C. T., et al, Coalbed Methane Resources of the United States, The American Association of Petroleum Geologists, Studies in Geology Series No. 17, p. 273, 1984.

McCord, J.P., Geologic Overview, Coal, and Coalbed Methane Resources of the Greater Green River Coal Region, Wyoming and Colorado, McLean, Va., TRW Inc. [Prepared for the U.S. Department of Energy Morgantown Energy Technology Center].

McGookey, D.P, et al, Cretaceous System, in Geologic Atlas of the Rocky Mountain Region, Rocky Mountain Association of Petroleum Geologists, p. 190-228, 1972.

National Oceanic and Atmospheric Administration, 1974, Climate of the States, v. II, Western States: p. 961-975.

Paul, W. George, Boyer, Charles M.,II, Methane From Coal Deposits Technical Evaluation and Data Base (Reservoir Engineering and Analysis), Advanced Resources International, Inc., GRI Contract No. 5084-214-1066, In Quarterly Review of Methane From Coal Seams Technology, Gas Research Institute, Vol. 9, Numbers 3 and 4, 1992, p. 21.

Quarterly Review of Methane from Coal Seams Technology, Gas Research Institute, Vol. 7, No. 3 (July-September 1989), March, 1990.

Quarterly Review of Methane from Coal Seams Technology, Gas Research Institute, Vol. 7, No. 4 (September-December 1989), July, 1990.

Quarterly Review of Methane from Coal Seams Technology, Gas Research Institute, Vol. 8, No. 2 (April-June 1990), February, 1991.

Quarterly Review of Methane from Coal Seams Technology, Gas Research Institute, Vol. 11, No. 1 (January-March 1993), August, 1993.

Surdam, R.C, et al, The Stratigraphic and Sedimentological Framework of the Green River, Formation, Wyoming, in Stratigraphy of Wyoming, Wyoming Geological Association, 31st Annual Field Conference, Guidebook, pp. 205-219, 1980. 
Taylor, James O., etal, Upper Colorado River Basin Regional Aquifer - System Study, in Regional Aquifer - System Analysis Program of the United States Geological Survey, Summary of Projects, United States Geological Survey Circular 1002, 1978-84.

Thomas, H. D., The Geological History and Geological Structure of Wyoming, The Geological Survey of Wyoming, October, 1949.

Welder, G. E. and L. J. McGreevy, Groundwater Reconnaissance of the Great Divide and Washakie Basins and some adjacent area, Southwestern Wyoming: U.S., 1966. 
